\title{
Biological consequences of dysfunctional HDL
}

\section{Pirillo Angela ${ }^{1,2}$, Catapano Alberico Luigi ${ }^{2,3}$, Norata Giuseppe Danilo ${ }^{1,3,4}$}

\author{
${ }^{1}$ Center for the Study of Atherosclerosis, Bassini Hospital, Cinisello Balsamo, Italy \\ ${ }^{2}$ IRCCS Multimedica, Milan, Italy \\ ${ }^{3}$ Department of Pharmacological and Biomolecular Sciences, Università degli Studi di \\ Milano, Milan, Italy \\ 4 School of Biomedical Sciences, Curtin Health Innovation Research Institute, Curtin \\ University, Perth, Western Australia.
}

\section{Corresponding Authors}

\section{Alberico L. Catapano}

Department of Pharmacological and Biomolecular Sciences, University of Milan and IRCCS Multimedica

Via Balzaretti, 9 - 20133 Milan ITALY

Phone number: +39250318302

Fax number: +39250318386

e-mail: alberico.catapano@unimi.it

\section{A ngela Pirillo}

Center for the Study of Atherosclerosis, E. Bassini Hospital

Via M. Gorki 50 - Cinisello Balsamo, Milan, Italy

Phone number: +39026173276

Fax number: +390266594941

e-mail: angela.pirillo@guest.unimi.it 


\section{Abstract}

Epidemiological studies have suggested an inverse correlation between high density lipoprotein (HDL) cholesterol levels and the risk of cardiovascular disease. HDLs promote reverse cholesterol transport (RCT) and possess several putative atheroprotective functions, associated to the anti-inflammatory, anti-thrombotic and anti-oxidant properties as well as to the ability to support endothelial physiology.

The assumption that increasing HDL-C levels would be beneficial on cardiovascular disease (CVD), however, has been questioned as, in most clinical trials, HDL-C-raising therapies did not result in improved cardiovascular outcomes. These findings, together with the observations from Mendelian randomization studies showing that polymorphisms mainly or solely associated with increased HDL-C levels did not decrease the risk of myocardial infarction, shift the focus from HDL-C levels toward HDL functional properties. Indeed, HDL from atherosclerotic patients not only exhibit impaired atheroprotective functions but also acquire pro-atherogenic properties and are referred to as "dysfunctional" HDL; this occurs even in the presence of normal or elevated HDL-C levels. Pharmacological approaches aimed at restoring HDL functions may therefore impact more significantly on CVD outcome than drugs used so far to increase HDL-C levels. Aims of this review is to discuss the pathological conditions leading to the formation of dysfunctional HDL and their role in atherosclerosis and beyond.

Keywords: high density lipoprotein; dysfunctional HDL; HDL quality; HDL subfractions; atherosclerosis; cardiovascular disease; 


\section{Introduction}

Epidemiological studies have suggested an inverse relationship between high density lipoprotein (HDL) cholesterol (HDL-C) levels and the risk of atherosclerotic cardiovascular disease [1]. The atheroprotective role of HDL is related to their key function in reverse cholesterol transport (RCT), as well as a number of additional potentially favorable properties including anti-inflammatory, antithrombotic, and antioxidant effects (Figure 1) [2]. Accordingly, several efforts to develop drugs to increase HDL-C levels have been undertaken [3]. These approaches, including those aimed at increasing apolipoprotein A-I (apoA-I) levels, have shown some beneficial effects either in preclinical studies [4-6] or in patients with coronary heart disease (CHD) [7-10]. However, recent clinical trials evaluating the effects of HDL-C-raising therapies have failed to demonstrate a benefit on cardiovascular outcomes [1113], with the exception of the recent REVEAL study on anacetrapib [14]. In addition, Mendelian randomization analyses have shown that single nucleotide polymorphisms that exclusively associate with higher HDL-C levels do not associate with a reduced risk of myocardial infarction [15]. These findings, together with the observation that the inverse relationship between HDLC levels and cardiovascular risk is present only in healthy subjects or in patients without CHD, while it is significantly weakened in patients with cardiovascular disease $[16,17]$, raised the question of whether HDL-C level is the right parameter to follow in clinic, and set the stage for testing the clinical relevance of changes in HDL function [18-20]. This possibility is supported by several observations: i) increased concentrations of lecithin-cholesterol acyltransferase (LCAT), which are associated with increased HDL-C levels, do not necessarily associate with atheroprotection and, conversely, LCAT deficiency, characterized by lower levels of HDL-C, does not associate with increased risk of atherosclerosis [21]. ii) HDL cholesterol efflux capacity is inversely associated with the incidence of cardiovascular events in a populationbased cohort free from cardiovascular disease, an association that persists even after adjustment for HDL-C levels or HDL particle concentrations [22] and predicts atherosclerotic burden better than HDL-C levels [22-25]. iii) The use of apoA-I mimetic peptides may improve HDL activities without changing its mass [26]. A recent study reported that the administration 
of the apoA-I mimetic peptide D-4F reduced the HDL-inflammatory burden in patients at high CHD risk, suggesting that this approach might result in improved HDL functions [27]. iv) Very high HDL-C levels and very large HDL particles associate with no cardiovascular benefit or even an increased risk of coronary artery disease (CAD) [28-30]. A possible explanation for these findings is related to the presence of "dysfunctional" HDL, i.e. HDL particles that have lost their atheroprotective functions and may be even pro-atherogenic (Figure 1). It is conceivable, therefore, that measuring HDL-C levels, although will capture the relative contribution of "protective HDL" not always will inform on their absolute levels or activity, and this might explain the observed disconnection of these measurements.

In this review we will discuss the biological effects of dysfunctional HDL and their possible relationship with atherosclerotic related diseases.

\section{HDL STRUCTURE, COMPOSITION AND FUNCTIONS}

HDL family includes both discoidal and spherical particles, heterogeneous in density, shape, size and electrophoretic mobility, which undergo continuous remodeling processes mediated by lipolytic enzymes and lipid transfer proteins. ApoA-I is the main apoprotein of HDL ( 70\%) and plays relevant functions either as structural or functional protein [31]. ApoA-II is the second major apolipoprotein of HDL ( $15-20 \%$ of total proteins) and has the ability to displace apoA-I from HDL. Increased levels of apoA-II associated-HDL therefore dampen the function of apoAI-containing HDL on reverse cholesterol transport, scavenger receptor class B type I (SR-BI) dependent hepatic cholesterol catabolism as well as the activity of enzymes involved in HDL metabolism [32]. However, HDL carry additional apoproteins (including apoE, apoCs, apoA-IV, apoA-V, apoJ, apoF, apoM, apoL1), enzymes involved in lipid metabolism (including LCAT and phospholipid transfer protein [PLTP]) as well as antioxidant enzymes, such as paraoxonase 1 (PON1), platelet-activating factor-acetyl hydrolase (PAF-AH) and glutathione selenoperoxidase (GSPX), acute phase response proteins (including serum amyloid A [SAA]) and complement components [31].

Based on surface charge and shape, HDL may be distinguished in pre- $\beta$-migrating and $\alpha$ migrating particles. Pre- $\beta$ particles are mainly nascent discoidal lipoproteins containing apoA-I, 
phospholipids and free cholesterol and a very small core of neutral lipids, while $\alpha$-migrating particles are "mature" quasi-spherical lipoproteins containing a hydrophobic core of cholesteryl esters (CE) and triglycerides (TG). Based on their density, HDL can also be classified as the large lipid-rich HDL2 and the small dense HDL3 [31]. HDL2 and HDL3 can be further subfractionated into 5 distinct subpopulations by native gradient gel electrophoresis based on their size, resulting in HDL2a and $2 b$ and HDL3a, $3 b$ and $3 c$ [31]. Finally, HDL can be separated according to their apoprotein content into particles containing only apoA-I (LpA-I) or both apoA-I and apoA-II (LPA-I:A-II) [31] (Figure 2). Due to the different methodologies used to measure HDL subclasses, it is difficult to find relations among them. For this reason, a classification of HDL based on density and size has been proposed, leading to the identification of five HDL subclasses (very large, large, medium, small and very small HDL) which should help to identify a relationship between these subclasses and cardiovascular risk [33] (Figure 2).

HDL particles differ also for their proteome and lipidome, with some subfractions carrying specific and distinct components not present in others. For example, HDL3c particles carry predominantly some proteins (including apo], PON1, PLTP, PAF-AH) [34] associated with its high antioxidant capacity. Instead, apoE and apoCs are preferentially carried by HDL2 [35]; these apoE-rich, large HDL particles are involved in the reverse cholesterol transport process through the interaction with scavenger receptor type B class I (SR-BI) and ATP-binding cassette transporter G1 (ABCG1) [36]. Again, sphingosine-1-phosphate (S1P), a minor bioactive lipid, is associated mainly with HDL3 particles [37].

HDL possess several potential atheroprotective functions (Figure 1). The most studied property of HDL is its role in RCT, the process by which excess cholesterol is believed to be transported from the peripheral tissues to the liver for excretion [38-40]. This process involves two main steps (Figure 3). During the first step, lipid-free or lipid-poor apoA-I (referred to as pre- $\beta$ HDL) accepts cholesterol from membranes of lipid-loaded cells of the arterial wall through the interaction with ATP-cassette binding transporter A1 (ABCA1). Circulating LCAT then esterifies free cholesterol and generates more mature HDL particles ( $\alpha$-particles) 
containing a lipid core composed by highly hydrophobic lipids (mainly cholesteryl esters, CE) and that can further accept cholesterol from cells following the interaction with ABCG1, ABCG4 $[39,41,42]$ or SR-BI [43]. RCT is then completed by a third step during which CE are delivered to the liver; this occurs by two different mechanisms: 1) directly, through the interaction of hepatic SR-BI and mature HDL particles, 2) indirectly, following the cholesteryl ester transfer protein (CETP)-mediated transfer of CE from HDL particles to VLDL and LDL and subsequent clearance by hepatic LDLR [40].

HDL possess anti-inflammatory properties [44, 45]. Experimental evidence demonstrates that HDL inhibit the endothelial activation induced by inflammation: the expression of surface adhesion molecules and chemoattractant proteins is reduced [46-53], thus decreasing the recruitment of monocytes, dendritic cells and T lymphocytes at sites of inflammation [54] and controlling the immune response. HDL may also act on circulating leukocytes to limit inflammation, for example by inhibiting the activation of CD11b, a surface protein involved in monocytes adhesion [55]. In addition, HDL inhibit the inflammasome activation and its downstream inflammatory cytokines through several mechanisms, thus reducing inflammation [56]. Different HDL subfractions exhibit different anti-inflammatory properties, being small dense HDL3 more efficient than large HDL2 in inhibiting the expression of endothelial adhesion molecules [57]. HDL3, probably due to its unique proteome [34], possess the highest ability to prevent LDL oxidation as well as the OxLDL-induced apoptosis of endothelial cells [58, 59]. Small dense HDL3 remove oxidized lipids from lipoproteins and cellular membrane more efficiently that large HDL2, an effect probably related to a reduced content in sphingomyelin and free cholesterol [37] which increases the fluidity of the surface lipid monolayer and facilitates the incorporation of oxidized lipids [60]. Spherical HDL have a higher inhibitory effect compared with discoidal particles [61]. Both proteins and lipids associated with HDL contribute to its anti-inflammatory activity. Modifications of $\mathrm{HDL}$, such as glycation or oxidation, impair the anti-inflammatory capacity of HDL and instead generate particles with pro-inflammatory activity [62-65]. Furthermore, during an inflammatory response, HDL may undergo profound modifications both in mass and composition. Although it is difficult to 
establish whether changes in plasma lipoproteins simply reflect the severity of disease or can directly modify the host response to inflammation, low HDL-C levels inversely correlate with the severity of septic disease and associate with an exaggerated systemic inflammatory response [66]. Also in healthy subjects low HDL levels is associated with increased inflammatory response on endotoxin challenge compared to subjects with normal or high HDL levels [67], without differences in the HDL proteome [68].

By removing excess cholesterol from macrophages following the interaction with ABCA1 and ABCG1, apoA-I and HDL reduce the macrophage expression of pro-inflammatory mediators, including MCP-1 and CD11b and inhibits the proliferation of lymphocytes [69]. In addition, the removal of membrane cholesterol alter the composition of lipid rafts, membrane microdomains involved in several biological processes, and contribute to the tuning of the innate and the adaptive immune response, globally resulting in reduced inflammatory activity of macrophages and reduced lymphocyte activation [69-71].

Beside a direct anti-inflammatory effect, HDL may counteract some of the pro-atherogenic effects of oxidized LDL (OxLDL); as example, HDL were shown to inhibit modified-LDL-induced monocyte-endothelium interaction [72], to prevent OxLDL-induced inhibition of eNOS activation [73], as well as OxLDL-induced platelet aggregation and adhesion [74], endothelial cell death [75] and reactive oxygen species increase [76]. HDL prevent the effects of electronegative LDL naturally occurring in the plasma, whose concentration is increased in atherosclerosis-associated diseases, which exhibit a higher susceptibility to aggregation and may exert inflammatory effects [77]. HDL and apoA-I can also prevent the oxidation of LDL $[78,79]$ by binding and removing lipid hydroperoxides $[80,81]$, as well as LDL aggregation by interacting with hydrophobic domains of the lipoprotein thus blocking the interactions that lead to aggregation [82]. Besides apoA-I, other HDL-associated apolipoproteins contribute to the anti-oxidant function, including apoE2 isoform [83] and apoA-IV [84]. HDL carry additional antioxidant enzymes able to prevent lipid oxidation or degrade lipid hydroperoxides, including PON1 and PAF-AH [85]. 
HDL play a role also on endothelial function by stimulating the production of $\mathrm{NO}$ and prostacyclin (PGI2) in these cells [86]. The generation of NO occurs following the interaction of HDL with endothelial SR-BI [87] and subsequent activation of Akt, which in turn activates endothelial NO synthase (eNOS), which is localized in specialized membrane microdomains enriched in cholesterol named caveolae [88]. HDL also maintain the lipid environment in caveolae, thus promoting eNOS function [89] and the cyclooxygenase-2/PGI2 synthase coupling [90]. ApoA-I seems to play a relevant role in the vasodilatory effect of HDL [91], but also S1P and PON1 contribute to the ability of HDL to stimulate NO production [92-94]. Both HDL2 and HDL3 (HDL2>HDL3) induce PGI2 secretion from endothelial cells; on the other hand, HDL2 inhibit the release of the potent vasoconstrictor thromboxane A2 (TXA2), while HDL3 induce its release [95]. The ratio PGI2/TXA2 suggests a more favorable vasodilatory effect for the HDL2 subfraction.

Endothelial apoptosis may result in an increased permeability of vascular endothelium; in addition, dysregulated apoptosis of atherosclerotic plaque cells may be an unfavorable process leading to plaque instability $[96,97]$, and HDL may attenuate this process. In fact HDL inhibit macrophage [98] as well as endothelial cell apoptosis induced by different stimuli [59, 75, 99, 100]. ApoA-I and HDL-associated lysosphingolipids are the major components responsible for this effect $[98,99,101]$. HDL inhibits the apoptosis induced by several stimuli in endothelial cells $[59,99]$, macrophages [102] and other cell types. Both proteins and lipids contribute to the antiapoptotic effect of HDL. ApoA-I is the major protein involved in this process [59], but also HDL-associated lysosphingolipids $[37,101,103,104]$ and PON1 play a role as well [105]. Small dense HDL3c have been shown to be most potent anti-apoptotic particles [59, 106]. On the other hand, plasma HDL-C levels positively correlates with the number of endothelial progenitor cells (which play a role in endothelial injury-repair process), evaluated as endothelial colony-forming units in culture [107].

HDL possess also anti-thrombotic properties; in vitro, HDL inhibit platelet activity and the expression of endothelial tissue factor induced by thrombin [108, 109]; furthermore, HDL stimulate the synthesis of prostacyclin, which inhibit platelet aggregation, by supplying 
arachidonic acid and inducing the expression of cyclooxygenase-2 [46, 90, 110]. In addition, HDL and apoA-I inhibit the self-association of von Willebrand factor, a process involved in the binding of platelet and formation of occlusive thrombi in small vessels [111].

\section{PATHOPHYSIOLOGICAL MECHANISMS OF DYSFUNCTIONAL HDL GENERATION}

\section{DEFECTIVE HDL REMODELLING}

Several enzymes, proteins and receptors are involved in the metabolism and remodeling of $\mathrm{HDL}$; mutations in the genes encoding for these proteins have been associated with changes in HDL-C plasma levels as well as in the composition and function of HDL particles [112].

Under physiological conditions, LCAT plays a relevant role in HDL metabolism by mediating the esterification of free cholesterol (causing an increase in HDL size), which is then transferred from HDL to TG-rich lipoproteins by the action of CETP (Figure 3). The activity of CETP leads to the reduction of HDL-C levels and HDL particle size. In this way, following the activity of LCAT, the newly formed pre- $\beta$ particles are converted into mature, spherical $\alpha^{-}$ migrating HDL. The latter may be converted back to pre-B-HDL by the action of CETP and other lipases: CETP mediates the transfer of CE between HDL and TG-rich lipoproteins, generating TG-rich HDL, which can be further hydrolyzed by hepatic lipase (HL) to small, TGrich HDL particles (Figure 3). The joint action of CETP and HL promotes reduction in HDL size, formation of lipid-poor HDL particles, and shedding from HDL of lipid-free apoA-I, which can restart the lipidation cycle (Figure 3). Another critical enzyme in the metabolism of HDL is endothelial lipase (EL), synthesized and secreted by endothelial cells and involved in the hydrolysis of HDL phospholipids. Its activity results in the destabilization of HDL particle, shedding of poorly lipidated apoA-I and hepatic uptake of the remodeled HDL particle [113] (Figure 3). Thus, this enzyme serves as a negative regulator of plasma HDL-C levels, although its role in atherosclerosis is still unclear. While in vitro EL-mediated generation of lipid-poor apoA-I increased cholesterol efflux capacity, in vivo EL overexpression reduced HDL without apoA-I generation and with impaired serum cholesterol efflux capacity[114]. 
When the activity of one of these proteins involved in HDL metabolism is altered, the process of maturation and remodeling of $\mathrm{HDL}$ is affected, leading to the formation of "dysfunctional" lipoproteins. The deficiency of LCAT-mediated esterification of free cholesterol leads to defective HDL maturation, characterized by the accumulation of pre-ß-particles [115] (Figure 4). Reduced LCAT activity may be due to either mutations in the gene encoding for this protein or to pathological conditions, such as metabolic syndrome, type 2 diabetes or chronic kidney disease [116-118]. Genetic variants of LCAT reducing the activity of this protein are associated with reduced HDL-C plasma levels and alterations in HDL structure and particle distribution, with a selective depletion of large $\alpha$-particles and accumulation of small pre $\beta-H D L$ which also contain apoA-II [119]. These alterations in HDL particle distribution translated into an improved ability of serum from LCAT deficient patients to efflux cholesterol through the ABCA1 transporter [120]. A similar pattern was observed in patients with metabolic syndrome, who exhibited a slightly reduced LCAT mass, increased pre- $B$ HDL and increased ABCA1mediated cholesterol efflux [116]. This was accompanied by reduction of HDL particle size and number and triglyceride enrichment [116]. In spite of this effect, the impact of LCAT deficiency on atherosclerosis is debated with either increased or decreased intima-media thickness (IMT) reported $[120,121]$.

The activity of CETP, which remodels HDL particles and increases LDL-C and VLDL-C levels (Figure 5), is increased in some conditions, such as hyperlipidemia. Genetic studies and a Mendelian randomization analysis have suggested a reduced cardiovascular risk in subjects carrying polymorphisms associated with reduced CETP activity [15, 122-124]. Subjects with mutations leading to CETP deficiency exhibit, in fact, increased levels of HDL-C, lower levels of LDL-C and a reduced incidence of CHD [125]. In particular, CETP-deficient subjects had increased levels of large HDL2 particles associated with a higher SR-BI/ABCG1-mediated cholesterol efflux capacity compared with control subjects $[126,127]$. In addition, HDL isolated from CETP-deficient subjects exhibit normal anti-inflammatory and anti-oxidant properties $[128,129]$, although they are less effective in inducing NO production, probably due to a reduced S1P content [128], or to a reduced ability to interact with SR-BI [130]. The hypothesis 
that pharmacological inhibition of CETP might mimic the CETP-deficient phenotype, resulting in an overall improved HDL function and reduced cardiovascular risk, has been challenged by the results of clinical trials, which failed to show a cardiovascular benefit despite significant HDL-C level increase $[12,13,131]$. An exception is represented by anacetrapib that reduced the incidence of major coronary events compared with placebo in atorvastatin-treated patients with atherosclerotic vascular disease [14]. However, as anacetrapib also significantly reduced LDL-C levels, it is likely that the observed cardiovascular benefit depends on this effect [132]. A post-hoc analysis of 2 large prospective study, however, suggested that very large HDL particles, which are formed upon CETP inhibition, are associated with higher risk of cardiovascular events despite apoA-I remains negatively associated to CAD risk [29]. Recently it has been shown that, in CETP transgenic mice, cholesterol efflux as well as PON1 activity were significantly increased and reactive oxygen species decreased by evacetrapib, while anacetrapib had no effect, despite similar effects on lipids [133]. As a result, anacetrapib worsened endothelium-dependent acetylcoline-induced vasorelaxation while evacetrapib had no effect [133]. Furthermore, the ACCENTUATE study with evacetrapib [134] showed that, although the treatment increased cholesterol efflux capacity, it also generated HDL particles with increased apoC-III content. ApoC-III-enriched HDL are less functional [135, 136] and might perhaps provide apoC-III to the arterial wall, which may trigger an inflammatory process in endothelial cells, characterized by increased expression of pro-inflammatory cytokines and increased adhesion of monocytes, as well as alterations of endothelial apoptosis [135, 137139]. These findings suggest that, although effective in improving the overall lipid profile, pharmacological CETP inhibition might not associate to a vascular protective effect.

\section{MYELOPEROXIDASE-INDUCED MODIFICATION OF HDL}

One major pathway responsible for the generation of dysfunctional HDL involves myeloperoxidase (MPO), a heme protein overexpressed in human atherosclerotic lesions where it colocalizes also with macrophages [140]. Locally this enzyme produces hypoclorous acid $(\mathrm{HOCl})$ and peroxynitrite $\left(\mathrm{ONOO}^{-}\right)$which convert free and protein-bound tyrosine residues to 3- 
chlorotyrosine and 3-nitrotyrosine [140]. An increased expression of MPO has been observed during the progression of atherosclerotic lesion into atherosclerotic plaque, with a maximal expression immediately before plaque rupture $[141,142]$, which may suggest this enzyme as a marker of unstable advanced plaque. Accordingly, MPO was detected within atherosclerotic plaques of patients with acute coronary syndrome, in which was shown to form complexes with apoA-I [143]. Circulating HDL isolated from patients with cardiovascular disease, acute coronary syndrome or diabetes present high levels of both 3-chlorotyrosine and 3-nitrotyrosine [144-147]. Chlorinated and nitrated adducts have been detected in human atherosclerotic lesions where they co-localize with macrophages [144, 145, 148]. In vitro MPO chlorinates and nitrates tyrosine 192 residue of apoA-I $[149,150]$, a modification detected also in HDL isolated from human atherosclerotic tissues or diabetic subjects [146, 151]. The oxidation of this specific tyrosine residue results in an impaired ability of HDL to promote ABCA1-mediated cholesterol [144, 146, 150]. In vivo, the injection of MPO-oxidized apoA-I resulted in a significantly lower RCT compared to mice injected with native HDL [152]. Atherosclerotic plaques from mice injected with MPO-oxidized apoA-I were not different in size, but presented increased macrophage and lipid accumulation and reduced collagen content [152]. The latter observation is in line with the ability of chlorinated and nitrated HDL to inhibit SMC migration and exhibit a reduced ability to stimulate SMC proliferation, without significant effects on SMC apoptosis [153]. Furthermore, in experimental models of carotid stenosis, the injection of chlorinated or nitrated $\mathrm{HDL}$ resulted in increased neointima/media ratio and reduced SMC positive staining cells in the fibrous cap compared to native HDL-treated mice, thus suggesting that MPO-HDL might increase the vulnerability index of the plaque [153].

In humans, serum MPO/HDL particle ratio was directly associated to incident cardiovascular disease (CVD) in a population-based cohort free from CVD at baseline [154]. The observation that MPO/HDL particle ratio was directly associated with high-sensitivity C-reactive protein and IL-18, and inversely associated with PON1 arylesterase activity [155] further linked MPO-HDL with increased vascular inflammation. 


\section{HDL GLYCATION}

An increased generation of advanced glycation end products in a hallmark of diabetes. Nonenzymatic glycation may occur under conditions of chronic hyperglycemia (poorly controlled diabetes), leading to alterations of HDL composition (lipids, apoproteins and enzymes) and functionality [156]. In vitro, the exposure of endothelial cells to glycated HDL induces apoptosis by triggering mitochondrial dysfunction [157] and increases oxidative stress [158]. In addition, glycated HDL are less effective in counteracting the inhibitory effect of OxLDL on endothelium-dependent vasorelaxation [159] and trigger vascular smooth muscle cell proliferation and migration [160]. The glycation of apoA-I alters the conformation of the apoprotein in regions that are critical for LCAT activation [161], reduces its ability to promote cholesterol efflux from macrophages and to inhibit the expression of adhesion molecules and ROS formation $[62,162]$. In humans, apoA-I glycation is associated with the severity of CAD and coronary artery plaque progression in patients with type 2 diabetes $[163,164]$ and with a significantly reduced apoA-I half-life [165]. Furthermore, HDL isolated from type 2 diabetic patients exhibited a reduced ability to catabolize membrane lipid hydroperoxides [166], to reverse the OxLDL-induced inhibition of vasodilation [167] and overall a reduced antiinflammatory activity [168].

Altogether these observations suggest that modification of HDL in diabetes may significantly impair their athero-protective functions and may contribute to the increased cardiovascular risk.

\section{HDL ALTERATIONS DURING INFECTION/INFLAMMATION}

Lipid metabolism and lipoprotein composition are altered during infection, and the reduction of plasma HDL-C levels is associated with changes in HDL composition and size. ApoA-I and phospholipids are reduced while serum amyloid $A(S A A)$ and secretory phospholipase A2 (sPLA2) are increased in acute phase $\operatorname{HDL}[71,169]$. These changes appear to be associated with a protection toward infections and together with other immunomodulatory activities support the evolutionary conserved function of $\mathrm{HDL}$ in the immune response $[70,170]$. 
Following infection, total HDL particle number does not change, while a significant decrease in the number of small and medium size particles is observed [171]. SAA rapidly associates to $\mathrm{HDL}$ and promotes the displacement of apoA-I; thus becoming the main protein of acute-phase HDL $[172,173]$ while when the inflammatory triggers are removed, SAA is cleared rapidly over $\sim 72 \mathrm{~h},[174]$ and is slowly replaced by apoA-I during recovery [175]. In parallel, during infection, the content of other HDL associated proteins (PON1, PAF-AH) is decreased, while ceruloplasmin content increases, with a net effect of reduced anti-oxidant capacity $[176,177]$ and increased content of pro-atherogenic lipids $[178,179]$ (Table 1). Changes in HDL remodeling enzymes including the increase of endothelial lipase [180] and secretory phospholipase A2 [171] and the decrease of CETP and LCAT $[66,171]$ contribute to alter HDL lipid composition and is paralleled by the reduction of functionality $[171,181,182]$, including the ability to promote reverse cholesterol transport (Table 1)[183].

These observations indicate a role of HDL in the protection against sepsis and suggest the possibility that SAA-HDL could be a marker of an efficient immune response. Nevertheless a SAA-ApoA-I crosslink was observed in acute phase HDL which was proposed to contribute to the amyloidogenic potential of these proteins [184], further studies are needed to clarify this issue.

In summary, acute infections represent a conditions where HDL are rapidly and largely rearranged and represent a disease condition where pharmacological approaches aimed at improving HDL composition rather than HDL-C levels might play a role. Alterations in the function/composition of HDL particles may also result in the impairment of immune functions. Vice versa patients with autoimmune diseases (such as systemic lupus erythematosus or rheumatoid arthritis), which are at increased cardiovascular risk [185], present altered HDL functionality, including reduced cholesterol efflux capacity, reduced antioxidant properties, and increased pro-inflammatory index [186-192] (Table 1). 


\section{ALTERATIONS OF ATHEROPROTECTIVE PROPERTIES OF HDL IN CARDIOVASCULAR DISEASE}

Impaired cholesterol efflux capacity of HDL has been related to structural changes of HDL components; in particular, alterations of apoA-I, primarily due to oxidative modifications, account for this effect owing to a reduced ability of oxidized apoA-I to induce ABCA1-mediated cholesterol efflux in vitro [144, 150, 193-195]. Thus, HDL isolated from patients with cardiovascular disease have been shown to exhibit a reduced cholesterol efflux potential. This was observed with HDL isolated from patients with acute coronary syndrome or CAD patients compared with healthy subjects, despite similar levels of plasma HDL-C, which suggests an altered functionality of HDL (Table 1) [196]. Large HDL2 particles isolated from patients with familial hypercholesterolemia $(\mathrm{FH})$ have a reduced capacity to mediate free cholesterol efflux via both SR-BI- and ABCG1-dependent pathways [197]. It has also been shown a reduction of plasma pre- $\beta 1 \mathrm{HDL}$, the major acceptor of free cholesterol from cells, in a large cohort of patients with type 2 diabetes, which associates with reduced ABCA1-mediated cholesterol efflux (Table 1) [198]. Other HDL alterations have been associated to a reduced functionality. For example, patients with established CAD have HDL3 particles enriched in specific proteins involved in lipid metabolism, complement activation and inflammatory response, such as apoE, apoC-IV, apoA-IV and complement C3 (a major effector of the complement system); the higher levels of apoE found in HDL3 particles suggests a redistribution of apoE from HDL2 to HDL3 with a consequent impairment of the cholesterol efflux capacity in patients with CAD [199].

Other modifications of HDL3 in patients with cardiovascular disease may account for the reduced anti-oxidative activity, including a reduced content of PON1 and PAF-AH [177, 200] and a reduced phosphatidylcholine/sphingomyelin ratio, which may reflect increased surface rigidity [201] (Table 1 ).

. HDL modified in vitro as well as HDL isolated from patients with CAD, diabetes, metabolic syndrome, chronic kidney disease or acute coronary syndrome fail to stimulate endothelial eNOS-activating pathways and NO production [94, 202-204] (Table 1). 
HDL isolated from patients with stable CAD or acute coronary syndrome (ACS) lose their ability to inhibit endothelial cell apoptosis and instead activate pro-apoptotic pathways [135] (Table 1). The proteomic analysis of HDL showed a reduction in clusterin and increase in apoCIII content [135] (Table 1); in agreement cholesterol levels in apoC-III-containing HDL particles is positively associated with incident coronary heart disease [205]. In addition, HDL3 isolated from subjects with the metabolic syndrome exhibit reduced anti-apoptotic properties associated to altered physicochemical properties, including core CE depletion and TG enrichment [206].

\section{CLINICAL RELEVANCE OF DYSFUNCTIONAL HDL}

Under pathological conditions, HDL can become dysfunctional, independently of their plasma levels, due to compositional and functional changes of lipoprotein, as reported in Table 1. For example in patients with CAD, diabetes mellitus or chronic renal disease, HDL function is impaired [207-209], as they exhibit significantly reduced protective functions, and rather acquire pro-atherogenic features [42, 210-213]. Consistently, HDL cholesterol efflux capacity is strongly and inversely associated with both subclinical atherosclerosis and obstructive coronary disease even when adjusted for HDL-C and apoA-I levels [23].

Patients with acute coronary syndrome as well as with stable CAD exhibit a reduced HDLmediated cellular cholesterol efflux compared with healthy subjects, even when matched by HDL-C levels; interestingly, it was reported that the reduction in HDL-mediated cholesterol efflux capacity remains impaired also three months later the ACS [196]. ACS is characterized by a high degree of inflammation, which results in elevated levels of acute phase proteins such as CRP and SAA; thus it is plausible that, during ACS, HDL particles may shift to a proinflammatory profile. In fact, levels of apoA-IV were significantly decreased, while SAA and complement C3 were increased in HDL particles of patients with ACS [213], which may alter the functions of HDL. Alterations of the HDL proteome has been reported also in subjects with 
CAD [199, 214]. HDL2 isolated from patients with CAD, whose levels are reduced in patients with CAD, also have a higher content of apoC-III (an inhibitor of lipoprotein lipase) and contain less apoC-I (which inhibits CETP), which may alter the physiological remodeling of HDL particles and lead to the generation of dysfunctional HDL [214, 215].

Patients with $\mathrm{FH}$ are characterized by a large elevation of LDL-C, but other lipid abnormalities are present as well. As example, beside the overall lower levels of plasma HDLC, also qualitative alterations in this class of lipoproteins has been reported, including the enrichment in TG and sphingomyelin, a reduced ability to remove cholesterol from cells, as well as reduced anti-inflammatory and anti-oxidant capacities [216]. HDL2 and HDL3 levels are reduced compared with control subjects, and large HDL2 particles are less effective in promoting cholesterol efflux, probably due to modifications in their phospholipid content [197]. An inverse relationship between HDL efflux capacity and development of atherosclerosis in $\mathrm{FH}$ patients has been observed; specifically, significant inverse relationships between SR-BIdependent HDL2 efflux capacity and carotid intima-media thickness and between ABCG1dependent HDL2 efflux capacity and carotid intima-media thickness have been observed [197]. Of note, TG-enriched HDL3 isolated from FH patients showed a reduced capacity to inhibit the release of IL-8 from TNF-a-stimulated endothelial cells, but also the increased content in sphingomyelin and saturated fatty acid may contribute to the reduced anti-inflammatory activity of HDL3 $[201,217]$. Whether these alterations modulate the clinical phenotype of FH remains to be investigated.

A reduced arylesterase activity, catalyzed by HDL-associated PON1, is associated with a high systemic oxidative stress; it was shown that in patients with chronic heart failure (HF), impaired antioxidant function of HDL (measured as PON1 activity) was associated with adverse cardiac events and HF-related hospitalizations[218] as well as with a higher risk of incident long-term adverse cardiac events, independent of established clinical and biochemical risk factors [219]. In addition, impaired antioxidant function of HDL has been associated with premature acute myocardial infarction [220]. The impaired antioxidant activity of HDL was observed during the acute phase of acute myocardial infarction (AMI), but also persisted 
during the stable phase of the disease 1 year after the event [220]. The analysis of HDL particle size distribution indicated a reduced number of large HDL particles in patients with premature AMI [220]. Furthermore, the correlation of large and intermediate HDL particles with antioxidant function observed in control patients was lost in patients with premature AMI, which may suggest that the reduction of very large particles and the impaired function of large and medium particles might contribute to the pathogenesis of premature acute myocardial infarction, thus helping to explain the lost of the inverse relationship between HDL-C levels and CV risk in patients with CAD [16].

Subjects with type 2 diabetes mellitus (T2DM) have a greater risk of developing cardiovascular disease ; this disease is characterized by the presence of the "atherogenic dyslipidaemias", that includes high TG levels, high levels of small dense pro-atherogenic LDL and low HDL-C levels [221]. Beside the reduced HDL-C levels, HDL particles from diabetic patients are dysfunctional, due to both the presence of advanced glycation end products, and to the increased oxidative stress and inflammation that lead to HDL modification and may reduce their ability to promote cholesterol efflux [156] or their anti-inflammatory capacity [62]. In addition, HDL from type 2 diabetic patients with poor glycaemic control have lower antioxidant and anti-inflammatory activities compared with those from patients with good glycaemic control [222].

Chronic kidney disease is a pathological conditions in which the progressive loss of kidney function leads to the worsening of the characteristic dyslipidemic profile, with low plasma levels of HDL-C [223]; beside, several other alterations are present in these patients, including abnormalities of HDL metabolism, LCAT deficiency, modification of apoA-I, TG enrichment, defective cholesterol transport and impaired anti-inflammatory activity [224]. In CKD patients, $\mathrm{HDL}$ are not able to provide $\mathrm{NO}$ to the endothelium to a relevant extent, a mechanism dependent on the activation of toll-like receptor 2 [225].

As reported for CAD subjects, the inverse association between HDL-C levels and CVD risk is significantly attenuated as the glomerular filtration rate (a measure of renal function) decreases [209, 226]. The changes in HDL subfractions and their oxidized subfraction particles 
are related to the severity of the disease, and higher amount of oxidized HDL may contribute to the increased CV risk in patients with advanced CKD $[227,228]$. HDL from patients with end-stage renal disease on dialysis have a dramatically reduced cholesterol efflux capacity compared with matched subjects with normal kidney function, and statin therapy did not improve HDL efflux capacity [229]. The HDL anti-inflammatory activity was reduced, but in the subgroup of patients on statin therapy it was similar to that of control subjects taking statins [229]. The presence of dysfunctional HDL significantly associates with an overall worse condition, including significantly higher co-morbidities and a lower quality of life, in hemodialysis patients, as suggested by the observation that patients with a higher HDL proinflammatory index have a higher hazard ratio for death than those whose HDL maintain their anti-inflammatory properties [230].

\section{Conclusions}

Atherosclerosis and related diseases, as well as other pathological conditions including acute phase reactions and immune diseases, are associated with significant alterations in both HDL-C levels and HDL particle structure/composition. Although HDL-C levels inversely correlate with the risk of cardiovascular disease, the observation that such relationship is mitigated in patients with established cardiovascular disease, together with the findings that very high levels of HDL-C do not associate with cardiovascular benefit and even increased the risk of CAD, and that pharmacological inhibition of CETP does not translate into a cardiovascular benefit despite significant increase in HDL-C levels, limit the relevance of HDL-C levels as an index of atheroprotection but rather point toward the investigation of HDL function in atherosclerosis. In line with this hypothesis, clinical evidence suggests that high levels of HDLC not always are atheroprotective, and instead may mark pro-inflammatory/pro-atherogenic features. On the other hand, small peptides that mimic the function of apoA-I render HDL less inflammatory [27], promote macrophage reverse cholesterol transport [231] and inhibit LDL aggregation [232], and were found to be effective in several animal models of disease [233237]. These observations also reveal the limitations of measurements based only on the 
determination of HDL-C levels. A recent analysis of the JUPITER trial showed that, in patients in which the weight of the main cardiovascular risk factor, LDL-C, is significantly attenuated by the treatment with a statin, it is possible to highlight the clinical relevance of HDL functionality [238]. These results also suggested that pharmacological approaches aimed at increasing HDLC plasma levels may not automatically translate into a clinical benefit and instead treatments that control hypercholesterolemia/inflammation may also result in an improvement of HDL functionality. 
Table 1. Compositional and functional changes of HDL in pathological conditions

\begin{tabular}{|c|c|}
\hline ACS, CAD & $\begin{array}{l}\downarrow \text { HDL-mediated cholesterol efflux [196]; } \downarrow \text { HDL-mediated NO } \\
\text { stimulation[94]; } \downarrow \text { inhibition of superoxide production [94]; } \downarrow \text { anti- } \\
\text { inflammatory properties and } \uparrow \text { pro-inflammatory properties [94]; } \\
\downarrow \text { endothelial repair [94]; } \downarrow \text { PON1 activity [94]; } \downarrow \text { inhibition of endothelial } \\
\text { apoptosis, } \uparrow \text { pro-apoptotic pathways [135]; } \downarrow \text { clusterin content [135], } \\
\uparrow a p o C-I I I \text { content }[135,214] ; \downarrow \text { apoA-IV, } \uparrow S A A \text { and complement C3 } \\
\text { content [213] }\end{array}$ \\
\hline $\mathrm{FH}$ & $\begin{array}{l}\downarrow H D L-C \text { levels; } \downarrow \text { HDL-mediated cholesterol efflux }[197,217] ; \\
\downarrow \text { antioxidant properties [201]; } \downarrow \text { anti-inflammatory activity [201, 217]; } \\
\uparrow T G \text { and sphingomyelin content [216] }\end{array}$ \\
\hline T2DM & $\begin{array}{l}\downarrow \text { HDL-C levels; } \downarrow \text { pre-B1 HDL [198]; } \downarrow \text { ABCA1-mediated cholesterol } \\
\text { efflux[198]; } \downarrow \text { anti-inflammatory properties of apoA-I [62] and HDL } \\
\text { [222] }\end{array}$ \\
\hline $\mathrm{HF}$ & $\begin{array}{l}\uparrow H D L \text { inflammatory index }[239] ; \uparrow S A A \text { content }[239] ; \downarrow \text { PON1 activity } \\
{[218,239] \downarrow \text { efflux capacity [200] }}\end{array}$ \\
\hline MetS & $\begin{array}{l}\text { } T \text { TG content }[203], \downarrow \text { S1P content }[203], \downarrow \text { HDL-mediated eNOS } \\
\text { activation [203]; } \downarrow \text { anti-oxidative properties [240]; } \downarrow \text { anti-apoptotic } \\
\text { activity [206]; } \downarrow \text { CE and } \uparrow \text { TG content }[206]\end{array}$ \\
\hline Premature AMI & 个HDL inflammatory index [220]; $\downarrow$ number of large HDL particles [220] \\
\hline CKD & $\begin{array}{l}\downarrow H D L 2 \text { and } \uparrow H D L 3, \text { LCAT and HL deficiency, } \uparrow \text { CETP activity, } \uparrow \text { TG and } \\
\downarrow P L \text { content, } \downarrow \text { antioxidant and anti-inflammatory properties, } \downarrow R C T \\
{[224] ; \downarrow N O \text { production }[225]}\end{array}$ \\
\hline $\begin{array}{l}\text { Autoimmune } \\
\text { disease }\end{array}$ & $\begin{array}{l}\downarrow \text { cholesterol efflux capacity }[186,188,189] ; \downarrow \text { antioxidant capacity } \\
{[192] ; \text { inflammation }[190,191]}\end{array}$ \\
\hline $\begin{array}{l}\text { Acute phase } \\
\text { reaction }\end{array}$ & $\begin{array}{l}\downarrow \text { HDL cholesterol level }[183] ; \downarrow \text { cholesterol efflux capacity [183]; } \uparrow \text { SAA } \\
\text { content in HDL [183]; } \downarrow \text { PON1 and PAF-AH [176] }\end{array}$ \\
\hline
\end{tabular}

CAD, coronary artery disease; ACS, acute coronary syndrome; FH, familial hypercholesterolemia; T2DM, type 2 diabetes mellitus; HF, heart failure; MetS, metabolic syndrome; AMI, acute myocardial infarction; CKD, chronic kidney disease 


\section{Legend to the Figures}

Figure 1. Functions of HDL. HDL possess several atheroprotective properties; all these activities may be significantly impaired under pathological conditions, due to the generation of "dysfunctional" HDL.

Figure 2. Classification of HDL particles based on their physic-chemical properties. Several methodologies exist to separate HDL particles, based on their density, size, charge and composition.

Figure 3. HDL metabolism and remodeling. Pre- $\beta$ HDL particles acquire cholesterol and phospholipids from cells in extrahepatic tissues following the interaction with $A B C A 1$, thus generating particles that are more enriched in cholesterol. The enzyme LCAT esterifies the free cholesterol molecules to form cholesteryl ester, which migrate within the core of the HDL particle forming mature a-migrating spherical HDL particles. These mature HDL particles can acquire additional cholesterol following the interaction with ABCG1/ABCG4 transporters. CETP mediates the exchange of hydrophobic lipids ( $C E$ and TG) between HDL and apoB-containing lipoproteins, leading to CE depletion and TG enrichment of HDL. CE is delivered to the liver either following the interaction between large HDL and SR-BI or between apoB-containing lipoproteins and hepatic LDLR.

Figure 4. Role of LCAT in HDL metabolism. The free cholesterol acquired by pre- $B$ HDL following the interaction with ABCA1 is esterified by the action of LCAT. LCAT deficiencies lead to very low plasma levels of HDL-C and accumulation of pre- $B$ HDL particles. LCAT, lipoproteinassociated enzyme lecithin:cholesterol acyltransferase

Figure 5. Role of CETP in HDL metabolism. CETP reduces circulating levels of HDL-C by facilitating the transfer of CE from HDL particles to LDL/VLDL particles in exchange for TG. CETP deficiency results in the accumulation of large, cholesterol-rich HDL particles 


\section{Conflict of Interest}

The authors declare that there are no conflicts of interest for the submitted work. 


\section{References}

[1] Emerging Risk Factors Collaboration Di Angelantonio, E.; Sarwar, N.; Perry, P.; Kaptoge, S.; Ray, K.K.; Thompson, A.; Wood, A.M.; Lewington, S.; Sattar, N.; Packard, C.J.; Collins, R.; Thompson, S.G.; Danesh, J., Major lipids, apolipoproteins, and risk of vascular disease. Jama, 2009, 302, (18), 1993-2000.

[2] Kontush, A., HDL-mediated mechanisms of protection in cardiovascular disease. Cardiovasc Res, 2014, 103, (3), 341-349.

[3] Remaley, A.T.; Norata, G.D.; Catapano, A.L., Novel concepts in HDL pharmacology. Cardiovasc Res, 2014, 103, (3), 423-428.

[4] Parolini, C.; Marchesi, M.; Lorenzon, P.; Castano, M.; Balconi, E.; Miragoli, L.; Chaabane, L.; Morisetti, A.; Lorusso, V.; Martin, B.J.; Bisgaier, C.L.; Krause, B.; Newton, R.S.; Sirtori, C.R.; Chiesa, G., Doserelated effects of repeated ETC-216 (recombinant apolipoprotein A-I Milano/1-palmitoyl-2-oleoyl phosphatidylcholine complexes) administrations on rabbit lipid-rich soft plaques: in vivo assessment by intravascular ultrasound and magnetic resonance imaging. Journal of the American College of Cardiology, 2008, 51, (11), 1098-1103.

[5] Ibanez, B.; Vilahur, G.; Cimmino, G.; Speidl, W.S.; Pinero, A.; Choi, B.G.; Zafar, M.U.; Santos-Gallego, C.G.; Krause, B.; Badimon, L.; Fuster, V.; Badimon, J.J., Rapid change in plaque size, composition, and molecular footprint after recombinant apolipoprotein A-I Milano (ETC-216) administration: magnetic resonance imaging study in an experimental model of atherosclerosis. Journal of the American College of Cardiology, 2008, 51, (11), 1104-1109.

[6] Giannarelli, C.; Cimmino, G.; Ibanez, B.; Chiesa, G.; Garcia-Prieto, J.; Santos-Gallego, C.G.; AliqueAguilar, M.; Fuster, V.; Sirtori, C.; Badimon, J.J., Acute ApoA-I Milano administration induces plaque regression and stabilisation in the long term. Thromb Haemost, 2012, 108, (6), 1246-1248.

[7] Nissen, S.E.; Tsunoda, T.; Tuzcu, E.M.; Schoenhagen, P.; Cooper, C.J.; Yasin, M.; Eaton, G.M.; Lauer, M.A.; Sheldon, W.S.; Grines, C.L.; Halpern, S.; Crowe, T.; Blankenship, J.C.; Kerensky, R., Effect of recombinant ApoA-I Milano on coronary atherosclerosis in patients with acute coronary syndromes: a randomized controlled trial. Jama, 2003, 290, (17), 2292-2300.

[8] Tardif, J.C.; Gregoire, J.; L'Allier, P.L.; Ibrahim, R.; Lesperance, J.; Heinonen, T.M.; Kouz, S.; Berry, C.; Basser, R.; Lavoie, M.A.; Guertin, M.C.; Rodes-Cabau, J., Effects of reconstituted high-density lipoprotein infusions on coronary atherosclerosis: a randomized controlled trial. Jama, 2007, 297, (15), 1675-1682.

[9] Shaw, J.A.; Bobik, A.; Murphy, A.; Kanellakis, P.; Blombery, P.; Mukhamedova, N.; Woollard, K.; Lyon, S.; Sviridov, D.; Dart, A.M., Infusion of reconstituted high-density lipoprotein leads to acute changes in human atherosclerotic plaque. Circ Res, 2008, 103, (10), 1084-1091.

[10] Nicholls, S.J.; Tuzcu, E.M.; Sipahi, I.; Schoenhagen, P.; Crowe, T.; Kapadia, S.; Nissen, S.E., Relationship between atheroma regression and change in lumen size after infusion of apolipoprotein A-I Milano. Journal of the American College of Cardiology, 2006, 47, (5), 992-997.

[11] Boden, W.E.; Probstfield, J.L.; Anderson, T.; Chaitman, B.R.; Desvignes-Nickens, P.; Koprowicz, K.; McBride, R.; Teo, K.; Weintraub, W., Niacin in patients with low HDL cholesterol levels receiving intensive statin therapy. N Engl J Med, 2011, 365, (24), 2255-2267.

[12] Schwartz, G.G.; Olsson, A.G.; Abt, M.; Ballantyne, C.M.; Barter, P.J.; Brumm, J.; Chaitman, B.R.; Holme, I.M.; Kallend, D.; Leiter, L.A.; Leitersdorf, E.; McMurray, J.J.; Mundl, H.; Nicholls, S.J.; Shah, P.K.; Tardif, J.C.; Wright, R.S., Effects of dalcetrapib in patients with a recent acute coronary syndrome. $N$ Engl J Med, 2012, 367, (22), 2089-2099.

[13] Lincoff, A.M.; Nicholls, S.J.; Riesmeyer, J.S.; Barter, P.J.; Brewer, H.B.; Fox, K.A.A.; Gibson, C.M.; Granger, C.; Menon, V.; Montalescot, G.; Rader, D.; Tall, A.R.; McErlean, E.; Wolski, K.; Ruotolo, G.; Vangerow, B.; Weerakkody, G.; Goodman, S.G.; Conde, D.; McGuire, D.K.; Nicolau, J.C.; Leiva-Pons, J.L.; Pesant, Y.; Li, W.; Kandath, D.; Kouz, S.; Tahirkheli, N.; Mason, D.; Nissen, S.E.; Investigators, A., Evacetrapib and Cardiovascular Outcomes in High-Risk Vascular Disease. N Engl J Med, 2017, 376, (20), 1933-1942.

[14] The HPS3/TIMI55-REVEAL Collaborative Group. Effects of Anacetrapib in Patients with Atherosclerotic Vascular Disease. N Engl J Med, 2017. 
[15] Voight, B.F.; Peloso, G.M.; Orho-Melander, M.; Frikke-Schmidt, R.; Barbalic, M.; Jensen, M.K.; Hindy, G.; Holm, H.; Ding, E.L.; Johnson, T.; Schunkert, H.; Samani, N.J.; Clarke, R.; Hopewell, J.C.; Thompson, J.F.; Li, M.; Thorleifsson, G.; Newton-Cheh, C.; Musunuru, K.; Pirruccello, J.P.; Saleheen, D.; Chen, L.; Stewart, A.; Schillert, A.; Thorsteinsdottir, U.; Thorgeirsson, G.; Anand, S.; Engert, J.C.; Morgan, T.; Spertus, J.; Stoll, M.; Berger, K.; Martinelli, N.; Girelli, D.; McKeown, P.P.; Patterson, C.C.; Epstein, S.E.; Devaney, J.; Burnett, M.S.; Mooser, V.; Ripatti, S.; Surakka, I.; Nieminen, M.S.; Sinisalo, J.; Lokki, M.L.; Perola, M.; Havulinna, A.; de Faire, U.; Gigante, B.; Ingelsson, E.; Zeller, T.; Wild, P.; de Bakker, P.I.; Klungel, O.H.; Maitland-van der Zee, A.H.; Peters, B.J.; de Boer, A.; Grobbee, D.E.; Kamphuisen, P.W.; Deneer, V.H.; Elbers, C.C.; Onland-Moret, N.C.; Hofker, M.H.; Wijmenga, C.; Verschuren, W.M.; Boer, J.M.; van der Schouw, Y.T.; Rasheed, A.; Frossard, P.; Demissie, S.; Willer, C.; Do, R.; Ordovas, J.M.; Abecasis, G.R.; Boehnke, M.; Mohlke, K.L.; Daly, M.J.; Guiducci, C.; Burtt, N.P.; Surti, A.; Gonzalez, E.; Purcell, S.; Gabriel, S.; Marrugat, J.; Peden, J.; Erdmann, J.; Diemert, P.; Willenborg, C.; Konig, I.R.; Fischer, M.; Hengstenberg, C.; Ziegler, A.; Buysschaert, I.; Lambrechts, D.; Van de Werf, F.; Fox, K.A.; El Mokhtari, N.E.; Rubin, D.; Schrezenmeir, J.; Schreiber, S.; Schafer, A.; Danesh, J.; Blankenberg, S.; Roberts, R.; McPherson, R.; Watkins, H.; Hall, A.S.; Overvad, K.; Rimm, E.; Boerwinkle, E.; Tybjaerg-Hansen, A.; Cupples, L.A.; Reilly, M.P.; Melander, O.; Mannucci, P.M.; Ardissino, D.; Siscovick, D.; Elosua, R.; Stefansson, K.; O'Donnell, C.J.; Salomaa, V.; Rader, D.J.; Peltonen, L.; Schwartz, S.M.; Altshuler, D.; Kathiresan, S., Plasma HDL cholesterol and risk of myocardial infarction: a mendelian randomisation study. Lancet, 2012, 380, (9841), 572-580.

[16] Silbernagel, G.; Schottker, B.; Appelbaum, S.; Scharnagl, H.; Kleber, M.E.; Grammer, T.B.; Ritsch, A.; Mons, U.; Holleczek, B.; Goliasch, G.; Niessner, A.; Boehm, B.O.; Schnabel, R.B.; Brenner, H.; Blankenberg, S.; Landmesser, U.; Marz, W., High-density lipoprotein cholesterol, coronary artery disease, and cardiovascular mortality. Eur Heart J, 2013, 34, (46), 3563-3571.

[17] Marz, W.; Kleber, M.E.; Scharnagl, H.; Speer, T.; Zewinger, S.; Ritsch, A.; Parhofer, K.G.; von Eckardstein, A.; Landmesser, U.; Laufs, U., HDL cholesterol: reappraisal of its clinical relevance. Clinical research in cardiology : official journal of the German Cardiac Society, 2017.

[18] Pirillo, A.; Norata, G.D.; Catapano, A.L., Treating high density lipoprotein cholesterol (HDL-C): quantity versus quality. Curr Pharm Des, 2013, 19, (21), 3841-3857.

[19] Pirillo, A.; Tibolla, G.; Norata, G.D.; Catapano, A.L., HDL: to treat or not to treat? Curr Atheroscler Rep, 2014, 16, (8), 429.

[20] Pirillo, A.; Norata, G.D.; Catapano, A.L., High-density lipoprotein subfractions--what the clinicians need to know. Cardiology, 2013, 124, (2), 116-125.

[21] Ossoli, A.; Pavanello, C.; Calabresi, L., High-Density Lipoprotein, Lecithin: Cholesterol Acyltransferase, and Atherosclerosis. Endocrinology and metabolism, 2016, 31, (2), 223-229.

[22] Rohatgi, A.; Khera, A.; Berry, J.D.; Givens, E.G.; Ayers, C.R.; Wedin, K.E.; Neeland, I.J.; Yuhanna, I.S.; Rader, D.R.; de Lemos, J.A.; Shaul, P.W., HDL cholesterol efflux capacity and incident cardiovascular events. N Engl J Med, 2014, 371, (25), 2383-2393.

[23] Khera, A.V.; Cuchel, M.; de la Llera-Moya, M.; Rodrigues, A.; Burke, M.F.; Jafri, K.; French, B.C.; Phillips, J.A.; Mucksavage, M.L.; Wilensky, R.L.; Mohler, E.R.; Rothblat, G.H.; Rader, D.J., Cholesterol efflux capacity, high-density lipoprotein function, and atherosclerosis. N Engl J Med, 2011, 364, (2), 127-135.

[24] Saleheen, D.; Scott, R.; Javad, S.; Zhao, W.; Rodrigues, A.; Picataggi, A.; Lukmanova, D.; Mucksavage, M.L.; Luben, R.; Billheimer, J.; Kastelein, J.J.; Boekholdt, S.M.; Khaw, K.T.; Wareham, N.; Rader, D.J., Association of HDL cholesterol efflux capacity with incident coronary heart disease events: a prospective case-control study. Lancet Diabetes Endocrinol, 2015, 3, (7), 507-513.

[25] Ritsch, A.; Scharnagl, H.; Marz, W., HDL cholesterol efflux capacity and cardiovascular events. N Engl J Med, 2015, 372, (19), 1870-1871.

[26] Millar, J.S.; Cuchel, M., ApoA-I-Directed Therapies for the Management of Atherosclerosis. Curr Atheroscler Rep, 2015, 17, (10), 60.

[27] Dunbar, R.L.; Movva, R.; Bloedon, L.T.; Duffy, D.; Norris, R.B.; Navab, M.; Fogelman, A.M.; Rader, D.J., Oral Apolipoprotein A-I Mimetic D-4F Lowers HDL-Inflammatory Index in High-Risk Patients: A First-in- 
Human Multiple-Dose, Randomized Controlled Trial. Clinical and translational science, 2017, 10, (6), 455469.

[28] Vigna, G.B.; Satta, E.; Bernini, F.; Boarini, S.; Bosi, C.; Giusto, L.; Pinotti, E.; Tarugi, P.; Vanini, A.; Volpato, S.; Zimetti, F.; Zuliani, G.; Favari, E., Flow-mediated dilation, carotid wall thickness and HDL function in subjects with hyperalphalipoproteinemia. Nutrition, metabolism, and cardiovascular diseases : NMCD, 2014, 24, (7), 777-783.

[29] van der Steeg, W.A.; Holme, I.; Boekholdt, S.M.; Larsen, M.L.; Lindahl, C.; Stroes, E.S.; Tikkanen, M.J.; Wareham, N.J.; Faergeman, O.; Olsson, A.G.; Pedersen, T.R.; Khaw, K.T.; Kastelein, J.J., High-density lipoprotein cholesterol, high-density lipoprotein particle size, and apolipoprotein A-I: significance for cardiovascular risk: the IDEAL and EPIC-Norfolk studies. Journal of the American College of Cardiology, 2008, 51, (6), 634-642.

[30] Madsen, C.M.; Varbo, A.; Nordestgaard, B.G., Extreme high high-density lipoprotein cholesterol is paradoxically associated with high mortality in men and women: two prospective cohort studies. Eur Heart J, 2017, 38, (32), 2478-2486.

[31] Kontush, A.; Lindahl, M.; Lhomme, M.; Calabresi, L.; Chapman, M.J.; Davidson, W.S., Structure of HDL: particle subclasses and molecular components. Handb Exp Pharmacol, 2015, 224, 3-51.

[32] Chan, D.C.; Ng, T.W.; Watts, G.F., Apolipoprotein A-II: evaluating its significance in dyslipidaemia, insulin resistance, and atherosclerosis. Ann Med, 2012, 44, (4), 313-324.

[33] Rosenson, R.S.; Brewer, H.B., Jr.; Chapman, M.J.; Fazio, S.; Hussain, M.M.; Kontush, A.; Krauss, R.M.; Otvos, J.D.; Remaley, A.T.; Schaefer, E.J., HDL measures, particle heterogeneity, proposed nomenclature, and relation to atherosclerotic cardiovascular events. Clinical chemistry, 2011.

[34] Davidson, W.S.; Silva, R.A.; Chantepie, S.; Lagor, W.R.; Chapman, M.J.; Kontush, A., Proteomic analysis of defined HDL subpopulations reveals particle-specific protein clusters: relevance to antioxidative function. Arterioscler Thromb Vasc Biol, 2009, 29, (6), 870-876.

[35] Schaefer, E.J.; Foster, D.M.; Jenkins, L.L.; Lindgren, F.T.; Berman, M.; Levy, R.I.; Brewer, H.B., Jr., The composition and metabolism of high density lipoprotein subfractions. Lipids, 1979, 14, (5), 511-522.

[36] Mahley, R.W.; Huang, Y.; Weisgraber, K.H., Putting cholesterol in its place: apoE and reverse cholesterol transport. J Clin Invest, 2006, 116, (5), 1226-1229.

[37] Kontush, A.; Therond, P.; Zerrad, A.; Couturier, M.; Negre-Salvayre, A.; de Souza, J.A.; Chantepie, S.; Chapman, M.J., Preferential sphingosine-1-phosphate enrichment and sphingomyelin depletion are key features of small dense HDL3 particles: relevance to antiapoptotic and antioxidative activities. Arterioscler Thromb Vasc Biol, 2007, 27, (8), 1843-1849.

[38] Rader, D.J., Molecular regulation of HDL metabolism and function: implications for novel therapies. J Clin Invest, 2006, 116, (12), 3090-3100.

[39] von Eckardstein, A.; Nofer, J.R.; Assmann, G., High density lipoproteins and arteriosclerosis. Role of cholesterol efflux and reverse cholesterol transport. Arterioscler Thromb Vasc Biol, 2001, 21, (1), 13-27.

[40] Lewis, G.F.; Rader, D.J., New insights into the regulation of HDL metabolism and reverse cholesterol transport. Circ Res, 2005, 96, (12), 1221-1232.

[41] Wang, N.; Lan, D.; Chen, W.; Matsuura, F.; Tall, A.R., ATP-binding cassette transporters G1 and G4 mediate cellular cholesterol efflux to high-density lipoproteins. Proc Natl Acad Sci U S A, 2004, 101, (26), 9774-9779.

[42] Kontush, A.; Chapman, M.J., Antiatherogenic small, dense HDL--guardian angel of the arterial wall? Nat Clin Pract Cardiovasc Med, 2006, 3, (3), 144-153.

[43] Asztalos, B.F.; de la Llera-Moya, M.; Dallal, G.E.; Horvath, K.V.; Schaefer, E.J.; Rothblat, G.H., Differential effects of HDL subpopulations on cellular ABCA1- and SR-BI-mediated cholesterol efflux. J Lipid Res, 2005, 46, (10), 2246-2253.

[44] Assmann, G.; Nofer, J.R., Atheroprotective effects of high-density lipoproteins. Annu Rev Med, 2003, 54, 321-341.

[45] Barter, P.J.; Nicholls, S.; Rye, K.A.; Anantharamaiah, G.M.; Navab, M.; Fogelman, A.M., Antiinflammatory properties of HDL. Circ Res, 2004, 95, (8), 764-772. 
[46] Cockerill, G.W.; Rye, K.A.; Gamble, J.R.; Vadas, M.A.; Barter, P.J., High-density lipoproteins inhibit cytokine-induced expression of endothelial cell adhesion molecules. Arterioscler Thromb Vasc Biol, 1995, 15, (11), 1987-1994.

[47] Nofer, J.R.; Geigenmuller, S.; Gopfert, C.; Assmann, G.; Buddecke, E.; Schmidt, A., High density lipoprotein-associated lysosphingolipids reduce E-selectin expression in human endothelial cells. Biochem Biophys Res Commun, 2003, 310, (1), 98-103.

[48] Barter, P.J.; Baker, P.W.; Rye, K.A., Effect of high-density lipoproteins on the expression of adhesion molecules in endothelial cells. Curr Opin Lipidol, 2002, 13, (3), 285-288.

[49] Tolle, M.; Pawlak, A.; Schuchardt, M.; Kawamura, A.; Tietge, U.J.; Lorkowski, S.; Keul, P.; Assmann, G.; Chun, J.; Levkau, B.; van der Giet, M.; Nofer, J.R., HDL-associated lysosphingolipids inhibit NAD(P)H oxidase-dependent monocyte chemoattractant protein-1 production. Arterioscler Thromb Vasc Biol, 2008, 28, (8), 1542-1548.

[50] Bursill, C.A.; Castro, M.L.; Beattie, D.T.; Nakhla, S.; van der Vorst, E.; Heather, A.K.; Barter, P.J.; Rye, K.A., High-density lipoproteins suppress chemokines and chemokine receptors in vitro and in vivo. Arterioscler Thromb Vasc Biol, 2010, 30, (9), 1773-1778.

[51] Norata, G.D.; Pellegatta, F.; Hamsten, A.; Catapano, A.L.; Eriksson, P., Effects of HDL3 on the expression of matrix-degrading proteases in human endothelial cells. Int J Mol Med, 2003, 12, (1), 73-78.

[52] Norata, G.D.; Bjork, H.; Hamsten, A.; Catapano, A.L.; Eriksson, P., High-density lipoprotein subfraction 3 decreases ADAMTS-1 expression induced by lipopolysaccharide and tumor necrosis factoralpha in human endothelial cells. Matrix Biol, 2004, 22, (7), 557-560.

[53] Norata, G.D.; Callegari, E.; Marchesi, M.; Chiesa, G.; Eriksson, P.; Catapano, A.L., High-density lipoproteins induce transforming growth factor-beta2 expression in endothelial cells. Circulation, 2005, 111, (21), 2805-2811.

[54] Norata, G.D.; Marchesi, P.; Pirillo, A.; Uboldi, P.; Chiesa, G.; Maina, V.; Garlanda, C.; Mantovani, A.; Catapano, A.L., Long pentraxin 3 , a key component of innate immunity, is modulated by high-density lipoproteins in endothelial cells. Arterioscler Thromb Vasc Biol, 2008, 28, (5), 925-931.

[55] Murphy, A.J.; Woollard, K.J.; Hoang, A.; Mukhamedova, N.; Stirzaker, R.A.; McCormick, S.P.; Remaley, A.T.; Sviridov, D.; Chin-Dusting, J., High-density lipoprotein reduces the human monocyte inflammatory response. Arterioscler Thromb Vasc Biol, 2008, 28, (11), 2071-2077.

[56] Thacker, S.G.; Zarzour, A.; Chen, Y.; Alcicek, M.S.; Freeman, L.A.; Sviridov, D.O.; Demosky, S.J., Jr.; Remaley, A.T., High-density lipoprotein reduces inflammation from cholesterol crystals by inhibiting inflammasome activation. Immunology, 2016, 149, (3), 306-319.

[57] Baker, P.W.; Rye, K.A.; Gamble, J.R.; Vadas, M.A.; Barter, P.J., Phospholipid composition of reconstituted high density lipoproteins influences their ability to inhibit endothelial cell adhesion molecule expression. J Lipid Res, 2000, 41, (8), 1261-1267.

[58] Kontush, A.; Chantepie, S.; Chapman, M.J., Small, dense HDL particles exert potent protection of atherogenic LDL against oxidative stress. Arterioscler Thromb Vasc Biol, 2003, 23, (10), 1881-1888.

[59] de Souza, J.A.; Vindis, C.; Negre-Salvayre, A.; Rye, K.A.; Couturier, M.; Therond, P.; Chantepie, S.; Salvayre, R.; Chapman, M.J.; Kontush, A., Small, dense HDL 3 particles attenuate apoptosis in endothelial cells: pivotal role of apolipoprotein A-I. J Cell Mol Med, 2010, 14, (3), 608-620.

[60] Kontush, A.; Chapman, M.J., Antiatherogenic function of HDL particle subpopulations: focus on antioxidative activities. Curr Opin Lipidol, 2010, 21, (4), 312-318.

[61] Baker, P.W.; Rye, K.A.; Gamble, J.R.; Vadas, M.A.; Barter, P.J., Ability of reconstituted high density lipoproteins to inhibit cytokine-induced expression of vascular cell adhesion molecule-1 in human umbilical vein endothelial cells. J Lipid Res, 1999, 40, (2), 345-353.

[62] Nobecourt, E.; Tabet, F.; Lambert, G.; Puranik, R.; Bao, S.; Yan, L.; Davies, M.J.; Brown, B.E.; Jenkins, A.J.; Dusting, G.J.; Bonnet, D.J.; Curtiss, L.K.; Barter, P.J.; Rye, K.A., Nonenzymatic glycation impairs the antiinflammatory properties of apolipoprotein A-I. Arterioscler Thromb Vasc Biol, 2010, 30, (4), 766-772. 
[63] Pirillo, A.; Uboldi, P.; Bolego, C.; Kuhn, H.; Catapano, A.L., The 15-lipoxygenase-modified high density lipoproteins 3 fail to inhibit the TNF-alpha-induced inflammatory response in human endothelial cells. J Immunol, 2008, 181, (4), 2821-2830.

[64] Kameda, T.; Ohkawa, R.; Yano, K.; Usami, Y.; Miyazaki, A.; Matsuda, K.; Kawasaki, K.; Sugano, M.; Kubota, T.; Tozuka, M., Effects of Myeloperoxidase-Induced Oxidation on Antiatherogenic Functions of High-Density Lipoprotein. Journal of lipids, 2015, 2015, 592594.

[65] Undurti, A.; Huang, Y.; Lupica, J.A.; Smith, J.D.; DiDonato, J.A.; Hazen, S.L., Modification of high density lipoprotein by myeloperoxidase generates a pro-inflammatory particle. J Biol Chem, 2009, 284, (45), 30825-30835.

[66] Wendel, M.; Paul, R.; Heller, A.R., Lipoproteins in inflammation and sepsis. II. Clinical aspects. Intensive Care Med, 2007, 33, (1), 25-35.

[67] Birjmohun, R.S.; van Leuven, S.I.; Levels, J.H.; van 't Veer, C.; Kuivenhoven, J.A.; Meijers, J.C.; Levi, M.; Kastelein, J.J.; van der Poll, T.; Stroes, E.S., High-density lipoprotein attenuates inflammation and coagulation response on endotoxin challenge in humans. Arterioscler Thromb Vasc Biol, 2007, 27, (5), 11531158.

[68] Levels, J.H.; Geurts, P.; Karlsson, H.; Maree, R.; Ljunggren, S.; Fornander, L.; Wehenkel, L.; Lindahl, M.; Stroes, E.S.; Kuivenhoven, J.A.; Meijers, J.C., High-density lipoprotein proteome dynamics in human endotoxemia. Proteome Sci, 2011, 9, (1), 34.

[69] Norata, G.D.; Pirillo, A.; Ammirati, E.; Catapano, A.L., Emerging role of high density lipoproteins as a player in the immune system. Atherosclerosis, 2012, 220, (1), 11-21.

[70] Norata, G.D.; Pirillo, A.; Catapano, A.L., HDLs, immunity, and atherosclerosis. Curr Opin Lipidol, 2011, 22, (5), 410-416.

[71] Catapano, A.L.; Pirillo, A.; Bonacina, F.; Norata, G.D., HDL in innate and adaptive immunity. Cardiovasc Res, 2014, 103, (3), 372-383.

[72] Watson, A.D.; Berliner, J.A.; Hama, S.Y.; La Du, B.N.; Faull, K.F.; Fogelman, A.M.; Navab, M., Protective effect of high density lipoprotein associated paraoxonase. Inhibition of the biological activity of minimally oxidized low density lipoprotein. J Clin Invest, 1995, 96, (6), 2882-2891.

[73] Uittenbogaard, A.; Shaul, P.W.; Yuhanna, I.S.; Blair, A.; Smart, E.J., High density lipoprotein prevents oxidized low density lipoprotein-induced inhibition of endothelial nitric-oxide synthase localization and activation in caveolae. J Biol Chem, 2000, 275, (15), 11278-11283.

[74] Badrnya, S.; Assinger, A.; Volf, I., Native high density lipoproteins (HDL) interfere with platelet activation induced by oxidized low density lipoproteins (OxLDL). Int J Mol Sci, 2013, 14, (5), 10107-10121.

[75] Suc, I.; Escargueil-Blanc, I.; Troly, M.; Salvayre, R.; Negre-Salvayre, A., HDL and ApoA prevent cell death of endothelial cells induced by oxidized LDL. Arterioscler Thromb Vasc Biol, 1997, 17, (10), 2158-2166. [76] Robbesyn, F.; Garcia, V.; Auge, N.; Vieira, O.; Frisach, M.F.; Salvayre, R.; Negre-Salvayre, A., HDL counterbalance the proinflammatory effect of oxidized LDL by inhibiting intracellular reactive oxygen species rise, proteasome activation, and subsequent NF-kappaB activation in smooth muscle cells. FASEB journal : official publication of the Federation of American Societies for Experimental Biology, 2003, 17, (6), 743-745.

[77] Bancells, C.; Sanchez-Quesada, J.L.; Birkelund, R.; Ordonez-Llanos, J.; Benitez, S., HDL and electronegative LDL exchange anti- and pro-inflammatory properties. J Lipid Res, 2010, 51, (10), 2947-2956. [78] Parthasarathy, S.; Barnett, J.; Fong, L.G., High-density lipoprotein inhibits the oxidative modification of low-density lipoprotein. Biochim Biophys Acta, 1990, 1044, (2), 275-283.

[79] Mackness, M.I.; Abbott, C.; Arrol, S.; Durrington, P.N., The role of high-density lipoprotein and lipidsoluble antioxidant vitamins in inhibiting low-density lipoprotein oxidation. Biochem J, 1993, 294 (Pt 3), 829-834.

[80] Garner, B.; Waldeck, A.R.; Witting, P.K.; Rye, K.A.; Stocker, R., Oxidation of high density lipoproteins. II. Evidence for direct reduction of lipid hydroperoxides by methionine residues of apolipoproteins Al and All. J Biol Chem, 1998, 273, (11), 6088-6095. 
[81] Zerrad-Saadi, A.; Therond, P.; Chantepie, S.; Couturier, M.; Rye, K.A.; Chapman, M.J.; Kontush, A., HDL3-mediated inactivation of LDL-associated phospholipid hydroperoxides is determined by the redox status of apolipoprotein A-I and HDL particle surface lipid rigidity: relevance to inflammation and atherogenesis. Arterioscler Thromb Vasc Biol, 2009, 29, (12), 2169-2175.

[82] Khoo, J.C.; Miller, E.; McLoughlin, P.; Steinberg, D., Prevention of low density lipoprotein aggregation by high density lipoprotein or apolipoprotein A-I. J Lipid Res, 1990, 31, (4), 645-652.

[83] Sacre, S.M.; Stannard, A.K.; Owen, J.S., Apolipoprotein E (apoE) isoforms differentially induce nitric oxide production in endothelial cells. FEBS Lett, 2003, 540, (1-3), 181-187.

[84] Ostos, M.A.; Conconi, M.; Vergnes, L.; Baroukh, N.; Ribalta, J.; Girona, J.; Caillaud, J.M.; Ochoa, A.; Zakin, M.M., Antioxidative and antiatherosclerotic effects of human apolipoprotein A-IV in apolipoprotein E-deficient mice. Arterioscler Thromb Vasc Biol, 2001, 21, (6), 1023-1028.

[85] Podrez, E.A., Anti-oxidant properties of high-density lipoprotein and atherosclerosis. Clin Exp Pharmacol Physiol, 2010, 37, (7), 719-725.

[86] Drew, B.G.; Fidge, N.H.; Gallon-Beaumier, G.; Kemp, B.E.; Kingwell, B.A., High-density lipoprotein and apolipoprotein Al increase endothelial NO synthase activity by protein association and multisite phosphorylation. Proc Natl Acad Sci U S A, 2004, 101, (18), 6999-7004.

[87] Yuhanna, I.S.; Zhu, Y.; Cox, B.E.; Hahner, L.D.; Osborne-Lawrence, S.; Lu, P.; Marcel, Y.L.; Anderson, R.G.; Mendelsohn, M.E.; Hobbs, H.H.; Shaul, P.W., High-density lipoprotein binding to scavenger receptor-BI activates endothelial nitric oxide synthase. Nature medicine, 2001, 7, (7), 853-857.

[88] Mineo, C.; Yuhanna, I.S.; Quon, M.J.; Shaul, P.W., High density lipoprotein-induced endothelial nitric-oxide synthase activation is mediated by Akt and MAP kinases. J Biol Chem, 2003, 278, (11), 9142 9149.

[89] Mineo, C.; Shaul, P.W., Regulation of eNOS in caveolae. Adv Exp Med Biol, 2012, 729, 51-62.

[90] Norata, G.D.; Callegari, E.; Inoue, H.; Catapano, A.L., HDL3 induces cyclooxygenase-2 expression and prostacyclin release in human endothelial cells via a p38 MAPK/CRE-dependent pathway: effects on COX2/PGI-synthase coupling. Arterioscler Thromb Vasc Biol, 2004, 24, (5), 871-877.

[91] de Beer, M.C.; Durbin, D.M.; Cai, L.; Jonas, A.; de Beer, F.C.; van der Westhuyzen, D.R., Apolipoprotein A-I conformation markedly influences HDL interaction with scavenger receptor BI. J Lipid Res, 2001, 42, (2), 309-313.

[92] Nofer, J.R.; van der Giet, M.; Tolle, M.; Wolinska, I.; von Wnuck Lipinski, K.; Baba, H.A.; Tietge, U.J.; Godecke, A.; Ishii, I.; Kleuser, B.; Schafers, M.; Fobker, M.; Zidek, W.; Assmann, G.; Chun, J.; Levkau, B., HDL induces NO-dependent vasorelaxation via the lysophospholipid receptor S1P3. J Clin Invest, 2004, 113, (4), 569-581.

[93] Sattler, K.; Levkau, B., Sphingosine-1-phosphate as a mediator of high-density lipoprotein effects in cardiovascular protection. Cardiovasc Res, 2009, 82, (2), 201-211.

[94] Besler, C.; Heinrich, K.; Rohrer, L.; Doerries, C.; Riwanto, M.; Shih, D.M.; Chroni, A.; Yonekawa, K.; Stein, S.; Schaefer, N.; Mueller, M.; Akhmedov, A.; Daniil, G.; Manes, C.; Templin, C.; Wyss, C.; Maier, W.; Tanner, F.C.; Matter, C.M.; Corti, R.; Furlong, C.; Lusis, A.J.; von Eckardstein, A.; Fogelman, A.M.; Luscher, T.F.; Landmesser, U., Mechanisms underlying adverse effects of HDL on eNOS-activating pathways in patients with coronary artery disease. J Clin Invest, 2011, 121, (7), 2693-2708.

[95] Oravec, S.; Demuth, K.; Myara, I.; Hornych, A., The effect of high density lipoprotein subfractions on endothelial eicosanoid secretion. Thromb Res, 1998, 92, (2), 65-71.

[96] Bombeli, T.; Karsan, A.; Tait, J.F.; Harlan, J.M., Apoptotic vascular endothelial cells become procoagulant. Blood, 1997, 89, (7), 2429-2442.

[97] Kockx, M.M.; Herman, A.G., Apoptosis in atherosclerosis: beneficial or detrimental? Cardiovasc Res, 2000, 45, (3), 736-746.

[98] Feuerborn, R.; Becker, S.; Poti, F.; Nagel, P.; Brodde, M.; Schmidt, H.; Christoffersen, C.; Ceglarek, U.; Burkhardt, R.; Nofer, J.R., High density lipoprotein (HDL)-associated sphingosine 1-phosphate (S1P) inhibits macrophage apoptosis by stimulating STAT3 activity and survivin expression. Atherosclerosis, 2017, 257, 29-37. 
[99] Nofer, J.R.; Levkau, B.; Wolinska, I.; Junker, R.; Fobker, M.; von Eckardstein, A.; Seedorf, U.; Assmann, G., Suppression of endothelial cell apoptosis by high density lipoproteins (HDL) and HDLassociated lysosphingolipids. J Biol Chem, 2001, 276, (37), 34480-34485.

[100] Sugano, M.; Tsuchida, K.; Makino, N., High-density lipoproteins protect endothelial cells from tumor necrosis factor-alpha-induced apoptosis. Biochem Biophys Res Commun, 2000, 272, (3), 872-876.

[101] Kimura, T.; Sato, K.; Kuwabara, A.; Tomura, H.; Ishiwara, M.; Kobayashi, I.; Ui, M.; Okajima, F., Sphingosine 1-phosphate may be a major component of plasma lipoproteins responsible for the cytoprotective actions in human umbilical vein endothelial cells. J Biol Chem, 2001, 276, (34), 31780-31785. [102] Terasaka, N.; Wang, N.; Yvan-Charvet, L.; Tall, A.R., High-density lipoprotein protects macrophages from oxidized low-density lipoprotein-induced apoptosis by promoting efflux of 7-ketocholesterol via ABCG1. Proc Natl Acad Sci U S A, 2007, 104, (38), 15093-15098.

[103] Theilmeier, G.; Schmidt, C.; Herrmann, J.; Keul, P.; Schafers, M.; Herrgott, I.; Mersmann, J.; Larmann, J.; Hermann, S.; Stypmann, J.; Schober, O.; Hildebrand, R.; Schulz, R.; Heusch, G.; Haude, M.; von Wnuck Lipinski, K.; Herzog, C.; Schmitz, M.; Erbel, R.; Chun, J.; Levkau, B., High-density lipoproteins and their constituent, sphingosine-1-phosphate, directly protect the heart against ischemia/reperfusion injury in vivo via the S1P3 lysophospholipid receptor. Circulation, 2006, 114, (13), 1403-1409.

[104] Frias, M.A.; Lang, U.; Gerber-Wicht, C.; James, R.W., Native and reconstituted HDL protect cardiomyocytes from doxorubicin-induced apoptosis. Cardiovasc Res, 2010, 85, (1), 118-126.

[105] Fuhrman, B.; Gantman, A.; Aviram, M., Paraoxonase 1 (PON1) deficiency in mice is associated with reduced expression of macrophage $\mathrm{SR}-\mathrm{BI}$ and consequently the loss of HDL cytoprotection against apoptosis. Atherosclerosis, 2010, 211, (1), 61-68.

[106] Brodeur, M.R.; Brissette, L.; Falstrault, L.; Moreau, R., HDL3 reduces the association and modulates the metabolism of oxidized LDL by osteoblastic cells: a protection against cell death. Journal of cellular biochemistry, 2008, 105, (6), 1374-1385.

[107] Pellegatta, F.; Bragheri, M.; Grigore, L.; Raselli, S.; Maggi, F.M.; Brambilla, C.; Reduzzi, A.; Pirillo, A.; Norata, G.D.; Catapano, A.L., In vitro isolation of circulating endothelial progenitor cells is related to the high density lipoprotein plasma levels. Int J Mol Med, 2006, 17, (2), 203-208.

[108] Lerch, P.G.; Spycher, M.O.; Doran, J.E., Reconstituted high density lipoprotein (rHDL) modulates platelet activity in vitro and ex vivo. Thromb Haemost, 1998, 80, (2), 316-320.

[109] Viswambharan, H.; Ming, X.F.; Zhu, S.; Hubsch, A.; Lerch, P.; Vergeres, G.; Rusconi, S.; Yang, Z., Reconstituted high-density lipoprotein inhibits thrombin-induced endothelial tissue factor expression through inhibition of RhoA and stimulation of phosphatidylinositol 3-kinase but not Akt/endothelial nitric oxide synthase. Circ Res, 2004, 94, (7), 918-925.

[110] Pomerantz, K.B.; Fleisher, L.N.; Tall, A.R.; Cannon, P.J., Enrichment of endothelial cell arachidonate by lipid transfer from high density lipoproteins: relationship to prostaglandin 12 synthesis. J Lipid Res, 1985, 26, (10), 1269-1276.

[111] Chung, D.W.; Chen, J.; Ling, M.; Fu, X.; Blevins, T.; Parsons, S.; Le, J.; Harris, J.; Martin, T.R.; Konkle, B.A.; Zheng, Y.; Lopez, J.A., High-density lipoprotein modulates thrombosis by preventing von Willebrand factor self-association and subsequent platelet adhesion. Blood, 2016, 127, (5), 637-645.

[112] Norata, G.D.; Pirillo, A.; Catapano, A.L., Modified HDL: biological and physiopathological consequences. Nutrition, metabolism, and cardiovascular diseases : NMCD, 2006, 16, (5), 371-386.

[113] Annema, W.; Tietge, U.J., Role of hepatic lipase and endothelial lipase in high-density lipoproteinmediated reverse cholesterol transport. Curr Atheroscler Rep, 2011, 13, (3), 257-265.

[114] Schilcher, I.; Kern, S.; Hrzenjak, A.; Eichmann, T.O.; Stojakovic, T.; Scharnagl, H.; Duta-Mare, M.; Kratky, D.; Marsche, G.; Frank, S., Impact of Endothelial Lipase on Cholesterol Efflux Capacity of Serum and High-density Lipoprotein. Scientific reports, 2017, 7, (1), 12485.

[115] Calabresi, L.; Franceschini, G., Lecithin:cholesterol acyltransferase, high-density lipoproteins, and atheroprotection in humans. Trends Cardiovasc Med, 2010, 20, (2), 50-53. 
[116] Lucero, D.; Sviridov, D.; Freeman, L.; Lopez, G.I.; Fassio, E.; Remaley, A.T.; Schreier, L., Increased cholesterol efflux capacity in metabolic syndrome: Relation with qualitative alterations in HDL and LCAT. Atherosclerosis, 2015, 242, (1), 236-242.

[117] Awadallah, S.; Madkour, M.; Hamidi, R.A.; Alwafa, E.A.; Hattab, M.; Zakkour, B.; Al-Matroushi, A.; Ahmed, E.; Al-Kitbi, M., Plasma levels of Apolipoprotein A1 and Lecithin:Cholesterol Acyltransferase in type 2 diabetes mellitus: Correlations with haptoglobin phenotypes. Diabetes \& metabolic syndrome, 2017.

[118] Calabresi, L.; Simonelli, S.; Conca, P.; Busnach, G.; Cabibbe, M.; Gesualdo, L.; Gigante, M.; Penco, S.; Veglia, F.; Franceschini, G., Acquired lecithin:cholesterol acyltransferase deficiency as a major factor in lowering plasma HDL levels in chronic kidney disease. J Intern Med, 2015, 277, (5), 552-561.

[119] Calabresi, L.; Simonelli, S.; Gomaraschi, M.; Franceschini, G., Genetic lecithin:cholesterol acyltransferase deficiency and cardiovascular disease. Atherosclerosis, 2012, 222, (2), 299-306.

[120] Calabresi, L.; Favari, E.; Moleri, E.; Adorni, M.P.; Pedrelli, M.; Costa, S.; Jessup, W.; Gelissen, I.C.; Kovanen, P.T.; Bernini, F.; Franceschini, G., Functional LCAT is not required for macrophage cholesterol efflux to human serum. Atherosclerosis, 2009, 204, (1), 141-146.

[121] van den Bogaard, B.; Holleboom, A.G.; Duivenvoorden, R.; Hutten, B.A.; Kastelein, J.J.; Hovingh, G.K.; Kuivenhoven, J.A.; Stroes, E.S.; van den Born, B.J., Patients with low HDL-cholesterol caused by mutations in LCAT have increased arterial stiffness. Atherosclerosis, 2012, 225, (2), 481-485.

[122] Barter, P.J.; Brewer, H.B., Jr.; Chapman, M.J.; Hennekens, C.H.; Rader, D.J.; Tall, A.R., Cholesteryl ester transfer protein: a novel target for raising HDL and inhibiting atherosclerosis. Arterioscler Thromb Vasc Biol, 2003, 23, (2), 160-167.

[123] Thompson, A.; Di Angelantonio, E.; Sarwar, N.; Erqou, S.; Saleheen, D.; Dullaart, R.P.; Keavney, B.; Ye, Z.; Danesh, J., Association of cholesteryl ester transfer protein genotypes with CETP mass and activity, lipid levels, and coronary risk. Jama, 2008, 299, (23), 2777-2788.

[124] Johannsen, T.H.; Frikke-Schmidt, R.; Schou, J.; Nordestgaard, B.G.; Tybjaerg-Hansen, A., Genetic inhibition of CETP, ischemic vascular disease and mortality, and possible adverse effects. Journal of the American College of Cardiology, 2012, 60, (20), 2041-2048.

[125] Mabuchi, H.; Nohara, A.; Inazu, A., Cholesteryl ester transfer protein (CETP) deficiency and CETP inhibitors. Molecules and cells, 2014, 37, (11), 777-784.

[126] Matsuura, F.; Wang, N.; Chen, W.; Jiang, X.C.; Tall, A.R., HDL from CETP-deficient subjects shows enhanced ability to promote cholesterol efflux from macrophages in an apoE- and ABCG1-dependent pathway. J Clin Invest, 2006, 116, (5), 1435-1442.

[127] Miwa, K.; Inazu, A.; Kawashiri, M.; Nohara, A.; Higashikata, T.; Kobayashi, J.; Koizumi, J.; Nakajima, K.; Nakano, T.; Niimi, M.; Mabuchi, H.; Yamagishi, M., Cholesterol efflux from 7774 macrophages and Fu5AH hepatoma cells to serum is preserved in CETP-deficient patients. Clin Chim Acta, 2009, 402, (1-2), 19-24.

[128] Gomaraschi, M.; Ossoli, A.; Pozzi, S.; Nilsson, P.; Cefalu, A.B.; Averna, M.; Kuivenhoven, J.A.;

Hovingh, G.K.; Veglia, F.; Franceschini, G.; Calabresi, L., eNOS activation by HDL is impaired in genetic CETP deficiency. PLoS One, 2014, 9, (5), e95925.

[129] Chantepie, S.; Bochem, A.E.; Chapman, M.J.; Hovingh, G.K.; Kontush, A., High-density lipoprotein (HDL) particle subpopulations in heterozygous cholesteryl ester transfer protein (CETP) deficiency: maintenance of antioxidative activity. PLoS One, 2012, 7, (11), e49336.

[130] Rinninger, F.; Brundert, M.; Budzinski, R.M.; Fruchart, J.C.; Greten, H.; Castro, G.R., Scavenger receptor BI (SR-BI) mediates a higher selective cholesteryl ester uptake from LpA-I compared with LpA-I:A-II lipoprotein particles. Atherosclerosis, 2003, 166, (1), 31-40.

[131] Luscher, T.F.; Taddei, S.; Kaski, J.C.; Jukema, J.W.; Kallend, D.; Munzel, T.; Kastelein, J.J.; Deanfield, J.E., Vascular effects and safety of dalcetrapib in patients with or at risk of coronary heart disease: the dalVESSEL randomized clinical trial. Eur Heart J, 2012, 33, (7), 857-865.

[132] Ference, B.A.; Kastelein, J.J.P.; Ginsberg, H.N.; Chapman, M.J.; Nicholls, S.J.; Ray, K.K.; Packard, C.J.; Laufs, U.; Brook, R.D.; Oliver-Williams, C.; Butterworth, A.S.; Danesh, J.; Smith, G.D.; Catapano, A.L.; Sabatine, M.S., Association of Genetic Variants Related to CETP Inhibitors and Statins With Lipoprotein Levels and Cardiovascular Risk. Jama, 2017, 318, (10), 947-956. 
[133] Simic, B.; Mocharla, P.; Crucet, M.; Osto, E.; Kratzer, A.; Stivala, S.; Kuhnast, S.; Speer, T.; Doycheva, P.; Princen, H.M.; van der Hoorn, J.W.; Jukema, J.W.; Giral, H.; Tailleux, A.; Landmesser, U.; Staels, B.; Luscher, T.F., Anacetrapib, but not evacetrapib, impairs endothelial function in CETP-transgenic mice in spite of marked HDL-C increase. Atherosclerosis, 2017, 257, 186-194.

[134] Nicholls, S.J.; Ray, K.K.; Ballantyne, C.M.; Beacham, L.A.; Miller, D.L.; Ruotolo, G.; Nissen, S.E.; Riesmeyer, J.S.; Investigators, A., Comparative effects of cholesteryl ester transfer protein inhibition, statin or ezetimibe on lipid factors: The ACCENTUATE trial. Atherosclerosis, 2017, 261, 12-18.

[135] Riwanto, M.; Rohrer, L.; Roschitzki, B.; Besler, C.; Mocharla, P.; Mueller, M.; Perisa, D.; Heinrich, K.; Altwegg, L.; von Eckardstein, A.; Luscher, T.F.; Landmesser, U., Altered activation of endothelial anti- and proapoptotic pathways by high-density lipoprotein from patients with coronary artery disease: role of highdensity lipoprotein-proteome remodeling. Circulation, 2013, 127, (8), 891-904.

[136] Luo, M.; Liu, A.; Wang, S.; Wang, T.; Hu, D.; Wu, S.; Peng, D., ApoCIII enrichment in HDL impairs HDL-mediated cholesterol efflux capacity. Scientific reports, 2017, 7, (1), 2312.

[137] Tao, Y.; Xiong, Y.; Wang, H.; Chu, S.; Zhong, R.; Wang, J.; Wang, G.; Ren, X.; Yu, J., APOC3 induces endothelial dysfunction through TNF-alpha and JAM-1. Lipids Health Dis, 2016, 15, (1), 153.

[138] Zheng, C.; Azcutia, V.; Aikawa, E.; Figueiredo, J.L.; Croce, K.; Sonoki, H.; Sacks, F.M.; Luscinskas, F.W.; Aikawa, M., Statins suppress apolipoprotein ClII-induced vascular endothelial cell activation and monocyte adhesion. Eur Heart J, 2013, 34, (8), 615-624.

[139] Kawakami, A.; Aikawa, M.; Alcaide, P.; Luscinskas, F.W.; Libby, P.; Sacks, F.M., Apolipoprotein CIII induces expression of vascular cell adhesion molecule- 1 in vascular endothelial cells and increases adhesion of monocytic cells. Circulation, 2006, 114, (7), 681-687.

[140] Shao, B.; Oda, M.N.; Oram, J.F.; Heinecke, J.W., Myeloperoxidase: an oxidative pathway for generating dysfunctional high-density lipoprotein. Chem Res Toxicol, 2010, 23, (3), 447-454.

[141] Sugiyama, S.; Okada, Y.; Sukhova, G.K.; Virmani, R.; Heinecke, J.W.; Libby, P., Macrophage myeloperoxidase regulation by granulocyte macrophage colony-stimulating factor in human atherosclerosis and implications in acute coronary syndromes. Am J Pathol, 2001, 158, (3), 879-891.

[142] Ferrante, G.; Nakano, M.; Prati, F.; Niccoli, G.; Mallus, M.T.; Ramazzotti, V.; Montone, R.A.; Kolodgie, F.D.; Virmani, R.; Crea, F., High levels of systemic myeloperoxidase are associated with coronary plaque erosion in patients with acute coronary syndromes: a clinicopathological study. Circulation, 2010, $122,(24), 2505-2513$.

[143] Huang, Y.; Wu, Z.; Riwanto, M.; Gao, S.; Levison, B.S.; Gu, X.; Fu, X.; Wagner, M.A.; Besler, C.; Gerstenecker, G.; Zhang, R.; Li, X.M.; DiDonato, A.J.; Gogonea, V.; Tang, W.H.; Smith, J.D.; Plow, E.F.; Fox, P.L.; Shih, D.M.; Lusis, A.J.; Fisher, E.A.; DiDonato, J.A.; Landmesser, U.; Hazen, S.L., Myeloperoxidase, paraoxonase-1, and HDL form a functional ternary complex. J Clin Invest, 2013, 123, (9), 3815-3828.

[144] Bergt, C.; Pennathur, S.; Fu, X.; Byun, J.; O'Brien, K.; McDonald, T.O.; Singh, P.; Anantharamaiah, G.M.; Chait, A.; Brunzell, J.; Geary, R.L.; Oram, J.F.; Heinecke, J.W., The myeloperoxidase product hypochlorous acid oxidizes HDL in the human artery wall and impairs ABCA1-dependent cholesterol transport. Proc Natl Acad Sci U S A, 2004, 101, (35), 13032-13037.

[145] Pennathur, S.; Bergt, C.; Shao, B.; Byun, J.; Kassim, S.Y.; Singh, P.; Green, P.S.; McDonald, T.O.; Brunzell, J.; Chait, A.; Oram, J.F.; O'Brien, K.; Geary, R.L.; Heinecke, J.W., Human atherosclerotic intima and blood of patients with established coronary artery disease contain high density lipoprotein damaged by reactive nitrogen species. J Biol Chem, 2004, 279, (41), 42977-42983.

[146] Lu, N.; Xie, S.; Li, J.; Tian, R.; Peng, Y.Y., Myeloperoxidase-mediated oxidation targets serum apolipoprotein A-I in diabetic patients and represents a potential mechanism leading to impaired antiapoptotic activity of high density lipoprotein. Clin Chim Acta, 2015, 441, 163-170.

[147] Shao, B.; Tang, C.; Sinha, A.; Mayer, P.S.; Davenport, G.D.; Brot, N.; Oda, M.N.; Zhao, X.Q.; Heinecke, J.W., Humans with atherosclerosis have impaired ABCA1 cholesterol efflux and enhanced high-density lipoprotein oxidation by myeloperoxidase. Circ Res, 2014, 114, (11), 1733-1742.

[148] Zheng, L.; Nukuna, B.; Brennan, M.L.; Sun, M.; Goormastic, M.; Settle, M.; Schmitt, D.; Fu, X.; Thomson, L.; Fox, P.L.; Ischiropoulos, H.; Smith, J.D.; Kinter, M.; Hazen, S.L., Apolipoprotein A-I is a selective 
target for myeloperoxidase-catalyzed oxidation and functional impairment in subjects with cardiovascular disease. J Clin Invest, 2004, 114, (4), 529-541.

[149] Bergt, C.; Fu, X.; Huq, N.P.; Kao, J.; Heinecke, J.W., Lysine residues direct the chlorination of tyrosines in YXXK motifs of apolipoprotein A-I when hypochlorous acid oxidizes high density lipoprotein. $J$ Biol Chem, 2004, 279, (9), 7856-7866.

[150] Shao, B.; Bergt, C.; Fu, X.; Green, P.; Voss, J.C.; Oda, M.N.; Oram, J.F.; Heinecke, J.W., Tyrosine 192 in apolipoprotein $\mathrm{A}-\mathrm{I}$ is the major site of nitration and chlorination by myeloperoxidase, but only chlorination markedly impairs ABCA1-dependent cholesterol transport. J Biol Chem, 2005, 280, (7), 59835993.

[151] Shao, B.; Pennathur, S.; Heinecke, J.W., Myeloperoxidase targets apolipoprotein A-I, the major high density lipoprotein protein, for site-specific oxidation in human atherosclerotic lesions. J Biol Chem, 2012, 287, (9), 6375-6386.

[152] Hewing, B.; Parathath, S.; Barrett, T.; Chung, W.K.; Astudillo, Y.M.; Hamada, T.; Ramkhelawon, B.; Tallant, T.C.; Yusufishaq, M.S.; Didonato, J.A.; Huang, Y.; Buffa, J.; Berisha, S.Z.; Smith, J.D.; Hazen, S.L.; Fisher, E.A., Effects of native and myeloperoxidase-modified apolipoprotein a-I on reverse cholesterol transport and atherosclerosis in mice. Arterioscler Thromb Vasc Biol, 2014, 34, (4), 779-789.

[153] Zhou, B.; Zu, L.; Chen, Y.; Zheng, X.; Wang, Y.; Pan, B.; Dong, M.; Zhou, E.; Zhao, M.; Zhang, Y.; Zheng, L.; Gao, W., Myeloperoxidase-oxidized high density lipoprotein impairs atherosclerotic plaque stability by inhibiting smooth muscle cell migration. Lipids Health Dis, 2017, 16, (1), 3.

[154] Khine, H.W.; Teiber, J.F.; Haley, R.W.; Khera, A.; Ayers, C.R.; Rohatgi, A., Association of the serum myeloperoxidase/high-density lipoprotein particle ratio and incident cardiovascular events in a multi-ethnic population: Observations from the Dallas Heart Study. Atherosclerosis, 2017, 263, 156-162.

[155] The Diabetes Control and Complications Trial Research Group. The effect of intensive treatment of diabetes on the development and progression of long-term complications in insulin-dependent diabetes mellitus. . N Engl J Med, 1993, 329, (14), 977-986.

[156] Srivastava, R.A.K., Dysfunctional HDL in diabetes mellitus and its role in the pathogenesis of cardiovascular disease. Mol Cell Biochem, 2017.

[157] Matsunaga, T.; Iguchi, K.; Nakajima, T.; Koyama, I.; Miyazaki, T.; Inoue, I.; Kawai, S.; Katayama, S.; Hirano, K.; Hokari, S.; Komoda, T., Glycated high-density lipoprotein induces apoptosis of endothelial cells via a mitochondrial dysfunction. Biochem Biophys Res Commun, 2001, 287, (3), 714-720.

[158] Matsunaga, T.; Nakajima, T.; Miyazaki, T.; Koyama, I.; Hokari, S.; Inoue, I.; Kawai, S.; Shimomura, H.; Katayama, S.; Hara, A.; Komoda, T., Glycated high-density lipoprotein regulates reactive oxygen species and reactive nitrogen species in endothelial cells. Metabolism, 2003, 52, (1), 42-49.

[159] Brindisi, M.C.; Duvillard, L.; Monier, S.; Verges, B.; Persegol, L., Deleterious effect of glycation on the ability of HDL to counteract the inhibitory effect of oxidized LDL on endothelium-dependent vasorelaxation. Diabetes/metabolism research and reviews, 2013, 29, (8), 618-623.

[160] Du, Q.; Qian, M.M.; Liu, P.L.; Zhang, L.; Wang, Y.; Liu, D.H., Glycation of high-density lipoprotein triggers oxidative stress and promotes the proliferation and migration of vascular smooth muscle cells. J Geriatr Cardiol, 2017, 14, (7), 473-480.

[161] Nobecourt, E.; Davies, M.J.; Brown, B.E.; Curtiss, L.K.; Bonnet, D.J.; Charlton, F.; Januszewski, A.S.; Jenkins, A.J.; Barter, P.J.; Rye, K.A., The impact of glycation on apolipoprotein A-I structure and its ability to activate lecithin:cholesterol acyltransferase. Diabetologia, 2007, 50, (3), 643-653.

[162] Hoang, A.; Murphy, A.J.; Coughlan, M.T.; Thomas, M.C.; Forbes, J.M.; O'Brien, R.; Cooper, M.E.; Chin-Dusting, J.P.; Sviridov, D., Advanced glycation of apolipoprotein A-I impairs its anti-atherogenic properties. Diabetologia, 2007, 50, (8), 1770-1779.

[163] Pu, L.J.; Lu, L.; Zhang, R.Y.; Du, R.; Shen, Y.; Zhang, Q.; Yang, Z.K.; Chen, Q.J.; Shen, W.F., Glycation of apoprotein $\mathrm{A}-\mathrm{I}$ is associated with coronary artery plaque progression in type 2 diabetic patients. Diabetes Care, 2013, 36, (5), 1312-1320.

[164] Shen, Y.; Ding, F.H.; Sun, J.T.; Pu, L.J.; Zhang, R.Y.; Zhang, Q.; Chen, Q.J.; Shen, W.F.; Lu, L., Association of elevated apoA-I glycation and reduced HDL-associated paraoxonase1, 3 activity, and their 
interaction with angiographic severity of coronary artery disease in patients with type 2 diabetes mellitus. Cardiovasc Diabetol, 2015, 14, 52.

[165] Kashyap, S.R.; Osme, A.; Ilchenko, S.; Golizeh, M.; Lee, K.; Wang, S.; Bena, J.; Previs, S.F.; Smith, J.D.; Kasumov, T., Glycation Reduces the Stability of ApoAI and Increases HDL Dysfunction in Diet-controlled Type 2 Diabetes. The Journal of clinical endocrinology and metabolism, 2017.

[166] Mastorikou, M.; Mackness, B.; Liu, Y.; Mackness, M., Glycation of paraoxonase-1 inhibits its activity and impairs the ability of high-density lipoprotein to metabolize membrane lipid hydroperoxides. Diabetic medicine : a journal of the British Diabetic Association, 2008, 25, (9), 1049-1055.

[167] Persegol, L.; Verges, B.; Foissac, M.; Gambert, P.; Duvillard, L., Inability of HDL from type 2 diabetic patients to counteract the inhibitory effect of oxidised LDL on endothelium-dependent vasorelaxation. Diabetologia, 2006, 49, (6), 1380-1386.

[168] Liu, D.; Ji, L.; Zhang, D.; Tong, X.; Pan, B.; Liu, P.; Zhang, Y.; Huang, Y.; Su, J.; Willard, B.; Zheng, L., Nonenzymatic glycation of high-density lipoprotein impairs its anti-inflammatory effects in innate immunity. Diabetes/metabolism research and reviews, 2012, 28, (2), 186-195.

[169] Pirillo, A.; Catapano, A.L.; Norata, G.D., HDL in infectious diseases and sepsis. Handb Exp Pharmacol, 2015, 224, 483-508.

[170] Norata, G.D.; Pirillo, A.; Ammirati, E.; Catapano, A.L., Emerging role of high density lipoproteins as a player in the immune system. Atherosclerosis, 2011, 220, (1), 11-21.

[171] de la Llera Moya, M.; McGillicuddy, F.C.; Hinkle, C.C.; Byrne, M.; Joshi, M.R.; Nguyen, V.; TabitaMartinez, J.; Wolfe, M.L.; Badellino, K.; Pruscino, L.; Mehta, N.N.; Asztalos, B.F.; Reilly, M.P., Inflammation modulates human HDL composition and function in vivo. Atherosclerosis, 2012, 222, (2), 390-394.

[172] Khovidhunkit, W.; Kim, M.S.; Memon, R.A.; Shigenaga, J.K.; Moser, A.H.; Feingold, K.R.; Grunfeld, C., Effects of infection and inflammation on lipid and lipoprotein metabolism: mechanisms and consequences to the host. J Lipid Res, 2004, 45, (7), 1169-1196.

[173] Coetzee, G.A.; Strachan, A.F.; van der Westhuyzen, D.R.; Hoppe, H.C.; Jeenah, M.S.; de Beer, F.C., Serum amyloid A-containing human high density lipoprotein 3. Density, size, and apolipoprotein composition. J Biol Chem, 1986, 261, (21), 9644-9651.

[174] Uhlar, C.M.; Whitehead, A.S., Serum amyloid A, the major vertebrate acute-phase reactant. European journal of biochemistry, 1999, 265, (2), 501-523.

[175] van Leeuwen, H.J.; Heezius, E.C.; Dallinga, G.M.; van Strijp, J.A.; Verhoef, J.; van Kessel, K.P., Lipoprotein metabolism in patients with severe sepsis. Crit Care Med, 2003, 31, (5), 1359-1366.

[176] Feingold, K.R.; Memon, R.A.; Moser, A.H.; Grunfeld, C., Paraoxonase activity in the serum and hepatic mRNA levels decrease during the acute phase response. Atherosclerosis, 1998, 139, (2), 307-315. [177] Van Lenten, B.J.; Hama, S.Y.; de Beer, F.C.; Stafforini, D.M.; McIntyre, T.M.; Prescott, S.M.; La Du, B.N.; Fogelman, A.M.; Navab, M., Anti-inflammatory HDL becomes pro-inflammatory during the acute phase response. Loss of protective effect of HDL against LDL oxidation in aortic wall cell cocultures. $J$ Clin Invest, 1995, 96, (6), 2758-2767.

[178] Cao, Y.; Stafforini, D.M.; Zimmerman, G.A.; McIntyre, T.M.; Prescott, S.M., Expression of plasma platelet-activating factor acetylhydrolase is transcriptionally regulated by mediators of inflammation. $J$ Biol Chem, 1998, 273, (7), 4012-4020.

[179] Memon, R.A.; Fuller, J.; Moser, A.H.; Feingold, K.R.; Grunfeld, C., In vivo regulation of plasma platelet-activating factor acetylhydrolase during the acute phase response. Am J Physiol, 1999, 277, (1 Pt 2), R94-103.

[180] Badellino, K.O.; Wolfe, M.L.; Reilly, M.P.; Rader, D.J., Endothelial lipase is increased in vivo by inflammation in humans. Circulation, 2008, 117, (5), 678-685.

[181] Banka, C.L.; Yuan, T.; de Beer, M.C.; Kindy, M.; Curtiss, L.K.; de Beer, F.C., Serum amyloid A (SAA): influence on HDL-mediated cellular cholesterol efflux. J Lipid Res, 1995, 36, (5), 1058-1065.

[182] McGillicuddy, F.C.; de la Llera Moya, M.; Hinkle, C.C.; Joshi, M.R.; Chiquoine, E.H.; Billheimer, J.T.; Rothblat, G.H.; Reilly, M.P., Inflammation impairs reverse cholesterol transport in vivo. Circulation, 2009, $119,(8), 1135-1145$. 
[183] Zimetti, F.; De Vuono, S.; Gomaraschi, M.; Adorni, M.P.; Favari, E.; Ronda, N.; Ricci, M.A.; Veglia, F.; Calabresi, L.; Lupattelli, G., Plasma cholesterol homeostasis, HDL remodeling and function during the acute phase reaction. J Lipid Res, 2017.

[184] Digre, A.; Nan, J.; Frank, M.; Li, J.P., Heparin interactions with apoA1 and SAA in inflammationassociated HDL. Biochem Biophys Res Commun, 2016, 474, (2), 309-314.

[185] Hintenberger, R.; Falkinger, A.; Danninger, K.; Pieringer, H., Cardiovascular disease in patients with autoinflammatory syndromes. Rheumatol Int, 2017.

[186] Ammirati, E.; Bozzolo, E.P.; Contri, R.; Baragetti, A.; Palini, A.G.; Cianflone, D.; Banfi, M.; Uboldi, P.; Bottoni, G.; Scotti, I.; Pirillo, A.; Grigore, L.; Garlaschelli, K.; Monaco, C.; Catapano, A.L.; Sabbadini, M.G.; Manfredi, A.A.; Norata, G.D., Cardiometabolic and immune factors associated with increased common carotid artery intima-media thickness and cardiovascular disease in patients with systemic lupus erythematosus. Nutrition, metabolism, and cardiovascular diseases: NMCD, 2014, 24, (7), 751-759.

[187] Montecucco, F.; Favari, E.; Norata, G.D.; Ronda, N.; Nofer, J.R.; Vuilleumier, N., Impact of systemic inflammation and autoimmune diseases on apoA-I and HDL plasma levels and functions. Handb Exp Pharmacol, 2015, 224, 455-482.

[188] Charles-Schoeman, C.; Lee, Y.Y.; Grijalva, V.; Amjadi, S.; FitzGerald, J.; Ranganath, V.K.; Taylor, M.; McMahon, M.; Paulus, H.E.; Reddy, S.T., Cholesterol efflux by high density lipoproteins is impaired in patients with active rheumatoid arthritis. Ann Rheum Dis, 2012, 71, (7), 1157-1162.

[189] Ronda, N.; Favari, E.; Borghi, M.O.; Ingegnoli, F.; Gerosa, M.; Chighizola, C.; Zimetti, F.; Adorni, M.P.; Bernini, F.; Meroni, P.L., Impaired serum cholesterol efflux capacity in rheumatoid arthritis and systemic lupus erythematosus. Ann Rheum Dis, 2014, 73, (3), 609-615.

[190] McMahon, M.; Grossman, J.; FitzGerald, J.; Dahlin-Lee, E.; Wallace, D.J.; Thong, B.Y.; Badsha, H.; Kalunian, K.; Charles, C.; Navab, M.; Fogelman, A.M.; Hahn, B.H., Proinflammatory high-density lipoprotein as a biomarker for atherosclerosis in patients with systemic lupus erythematosus and rheumatoid arthritis. Arthritis Rheum, 2006, 54, (8), 2541-2549.

[191] Smith, C.K.; Seto, N.L.; Vivekanandan-Giri, A.; Yuan, W.; Playford, M.P.; Manna, Z.; Hasni, S.A.; Kuai, R.; Mehta, N.N.; Schwendeman, A.; Pennathur, S.; Kaplan, M.J., Lupus high-density lipoprotein induces proinflammatory responses in macrophages by binding lectin-like oxidised low-density lipoprotein receptor 1 and failing to promote activating transcription factor 3 activity. Ann Rheum Dis, 2017, 76, (3), 602-611. [192] Gaal, K.; Tarr, T.; Lorincz, H.; Borbas, V.; Seres, I.; Harangi, M.; Fulop, P.; Paragh, G., High-density lipopoprotein antioxidant capacity, subpopulation distribution and paraoxonase-1 activity in patients with systemic lupus erythematosus. Lipids Health Dis, 2016, 15, 60.

[193] Shao, B.; Oda, M.N.; Bergt, C.; Fu, X.; Green, P.S.; Brot, N.; Oram, J.F.; Heinecke, J.W., Myeloperoxidase impairs ABCA1-dependent cholesterol efflux through methionine oxidation and sitespecific tyrosine chlorination of apolipoprotein A-I. J Biol Chem, 2006, 281, (14), 9001-9004.

[194] Pirillo, A.; Uboldi, P.; Kuhn, H.; Catapano, A.L., 15-Lipoxygenase-mediated modification of highdensity lipoproteins impairs SR-BI- and ABCA1-dependent cholesterol efflux from macrophages. Biochim Biophys Acta, 2006, 1761, (3), 292-300.

[195] Pirillo, A.; Uboldi, P.; Catapano, A.L., Dual effect of hypochlorite in the modification of high density lipoproteins. Biochem Biophys Res Commun, 2010, 403, (3-4), 447-451.

[196] Hafiane, A.; Jabor, B.; Ruel, I.; Ling, J.; Genest, J., High-density lipoprotein mediated cellular cholesterol efflux in acute coronary syndromes. The American journal of cardiology, 2014, 113, (2), 249255.

[197] Bellanger, N.; Orsoni, A.; Julia, Z.; Fournier, N.; Frisdal, E.; Duchene, E.; Bruckert, E.; Carrie, A.; Bonnefont-Rousselot, D.; Pirault, J.; Saint-Charles, F.; Chapman, M.J.; Lesnik, P.; Le Goff, W.; Guerin, M., Atheroprotective reverse cholesterol transport pathway is defective in familial hypercholesterolemia. Arterioscler Thromb Vasc Biol, 2011, 31, (7), 1675-1681.

[198] Shiu, S.W.; Wong, Y.; Tan, K.C., Pre-beta1 HDL in type 2 diabetes mellitus. Atherosclerosis, 2017, 263, 24-28. 
[199] Vaisar, T.; Pennathur, S.; Green, P.S.; Gharib, S.A.; Hoofnagle, A.N.; Cheung, M.C.; Byun, J.; Vuletic, S.; Kassim, S.; Singh, P.; Chea, H.; Knopp, R.H.; Brunzell, J.; Geary, R.; Chait, A.; Zhao, X.Q.; Elkon, K.; Marcovina, S.; Ridker, P.; Oram, J.F.; Heinecke, J.W., Shotgun proteomics implicates protease inhibition and complement activation in the antiinflammatory properties of HDL. J Clin Invest, 2007, 117, (3), 746-756.

[200] Patel, P.J.; Khera, A.V.; Wilensky, R.L.; Rader, D.J., Anti-oxidative and cholesterol efflux capacities of high-density lipoprotein are reduced in ischaemic cardiomyopathy. European journal of heart failure, 2013, $15,(11), 1215-1219$.

[201] Hussein, H.; Saheb, S.; Couturier, M.; Atassi, M.; Orsoni, A.; Carrie, A.; Therond, P.; Chantepie, S.; Robillard, P.; Bruckert, E.; Chapman, M.J.; Kontush, A., Small, dense high-density lipoprotein 3 particles exhibit defective antioxidative and anti-inflammatory function in familial hypercholesterolemia: Partial correction by low-density lipoprotein apheresis. J Clin Lipidol, 2016, 10, (1), 124-133.

[202] Cutuli, L.; Pirillo, A.; Uboldi, P.; Kuehn, H.; Catapano, A.L., 15-lipoxygenase-mediated modification of HDL3 impairs eNOS activation in human endothelial cells. Lipids, 2014, 49, (4), 317-326.

[203] Denimal, D.; Monier, S.; Brindisi, M.C.; Petit, J.M.; Bouillet, B.; Nguyen, A.; Demizieux, L.; Simoneau, I.; Pais de Barros, J.P.; Verges, B.; Duvillard, L., Impairment of the Ability of HDL From Patients With Metabolic Syndrome but Without Diabetes Mellitus to Activate eNOS: Correction by S1P Enrichment. Arterioscler Thromb Vasc Biol, 2017, 37, (5), 804-811.

[204] Marsche, G.; Heller, R.; Fauler, G.; Kovacevic, A.; Nuszkowski, A.; Graier, W.; Sattler, W.; Malle, E., 2chlorohexadecanal derived from hypochlorite-modified high-density lipoprotein-associated plasmalogen is a natural inhibitor of endothelial nitric oxide biosynthesis. Arterioscler Thromb Vasc Biol, 2004, 24, (12), 2302-2306.

[205] Jensen, M.K.; Rimm, E.B.; Furtado, J.D.; Sacks, F.M., Apolipoprotein C-III as a potential modulator of the association between HDL-cholesterol and incident coronary heart disease. J Am Heart Assoc, 2012, 1, (2).

[206] de Souza, J.A.; Vindis, C.; Hansel, B.; Negre-Salvayre, A.; Therond, P.; Serrano, C.V., Jr.; Chantepie, S.; Salvayre, R.; Bruckert, E.; Chapman, M.J.; Kontush, A., Metabolic syndrome features small, apolipoprotein A-I-poor, triglyceride-rich HDL3 particles with defective anti-apoptotic activity. Atherosclerosis, 2008, 197, (1), 84-94.

[207] Annema, W.; von Eckardstein, A., Dysfunctional high-density lipoproteins in coronary heart disease: implications for diagnostics and therapy. Transl Res, 2016, 173, 30-57.

[208] Sorrentino, S.A.; Besler, C.; Rohrer, L.; Meyer, M.; Heinrich, K.; Bahlmann, F.H.; Mueller, M.; Horvath, T.; Doerries, C.; Heinemann, M.; Flemmer, S.; Markowski, A.; Manes, C.; Bahr, M.J.; Haller, H.; von Eckardstein, A.; Drexler, H.; Landmesser, U., Endothelial-vasoprotective effects of high-density lipoprotein are impaired in patients with type 2 diabetes mellitus but are improved after extended-release niacin therapy. Circulation, 2010, 121, (1), 110-122.

[209] Zewinger, S.; Speer, T.; Kleber, M.E.; Scharnagl, H.; Woitas, R.; Lepper, P.M.; Pfahler, K.; Seiler, S.; Heine, G.H.; Marz, W.; Silbernagel, G.; Fliser, D., HDL cholesterol is not associated with lower mortality in patients with kidney dysfunction. Journal of the American Society of Nephrology : JASN, 2014, 25, (5), 10731082.

[210] Fogelman, A.M., When good cholesterol goes bad. Nature medicine, 2004, 10, (9), 902-903.

[211] Navab, M.; Yu, R.; Gharavi, N.; Huang, W.; Ezra, N.; Lotfizadeh, A.; Anantharamaiah, G.M.; Alipour, N.; Van Lenten, B.J.; Reddy, S.T.; Marelli, D., High-density lipoprotein: antioxidant and anti-inflammatory properties. Curr Atheroscler Rep, 2007, 9, (3), 244-248.

[212] Ansell, B.J.; Navab, M.; Hama, S.; Kamranpour, N.; Fonarow, G.; Hough, G.; Rahmani, S.; Mottahedeh, R.; Dave, R.; Reddy, S.T.; Fogelman, A.M., Inflammatory/antiinflammatory properties of highdensity lipoprotein distinguish patients from control subjects better than high-density lipoprotein cholesterol levels and are favorably affected by simvastatin treatment. Circulation, 2003, 108, (22), 27512756. 
[213] Alwaili, K.; Bailey, D.; Awan, Z.; Bailey, S.D.; Ruel, I.; Hafiane, A.; Krimbou, L.; Laboissiere, S.; Genest, J., The HDL proteome in acute coronary syndromes shifts to an inflammatory profile. Biochim Biophys Acta, 2012, 1821, (3), 405-415.

[214] Vaisar, T.; Mayer, P.; Nilsson, E.; Zhao, X.Q.; Knopp, R.; Prazen, B.J., HDL in humans with cardiovascular disease exhibits a proteomic signature. Clin Chim Acta, 2010, 411, (13-14), 972-979.

[215] Drexel, H.; Amann, F.W.; Rentsch, K.; Neuenschwander, C.; Luethy, A.; Khan, S.I.; Follath, F., Relation of the level of high-density lipoprotein subfractions to the presence and extent of coronary artery disease. The American journal of cardiology, 1992, 70, (4), 436-440.

[216] Ganjali, S.; Momtazi, A.A.; Banach, M.; Kovanen, P.T.; Stein, E.A.; Sahebkar, A., HDL abnormalities in familial hypercholesterolemia: Focus on biological functions. Prog Lipid Res, 2017, 67, 16-26.

[217] Ottestad, I.O.; Halvorsen, B.; Balstad, T.R.; Otterdal, K.; Borge, G.I.; Brosstad, F.; Myhre, A.M.; Ose, L.; Nenseter, M.S.; Holven, K.B., Triglyceride-rich HDL3 from patients with familial hypercholesterolemia are less able to inhibit cytokine release or to promote cholesterol efflux. J Nutr, 2006, 136, (4), 877-881.

[218] Hammadah, M.; Kalogeropoulos, A.P.; Georgiopoulou, V.V.; Weber, M.; Wu, Y.; Hazen, S.L.; Butler, J.; Tang, W.H.W., High-density lipoprotein-associated paraoxonase-1 activity for prediction of adverse outcomes in outpatients with chronic heart failure. European journal of heart failure, 2017, 19, (6), 748755.

[219] Tang, W.H.; Wu, Y.; Mann, S.; Pepoy, M.; Shrestha, K.; Borowski, A.G.; Hazen, S.L., Diminished antioxidant activity of high-density lipoprotein-associated proteins in systolic heart failure. Circulation. Heart failure, 2011, 4, (1), 59-64.

[220] Distelmaier, K.; Wiesbauer, F.; Blessberger, H.; Oravec, S.; Schrutka, L.; Binder, C.; Dostal, E.; Schillinger, M.; Wojta, J.; Lang, I.M.; Maurer, G.; Huber, K.; Goliasch, G., Impaired antioxidant HDL function is associated with premature myocardial infarction. European journal of clinical investigation, 2015, 45, (7), 731-738.

[221] Xiao, C.; Dash, S.; Morgantini, C.; Hegele, R.A.; Lewis, G.F., Pharmacological targeting of the atherogenic dyslipidemia complex: the next frontier in CVD prevention beyond lowering LDL cholesterol. Diabetes, 2016, 65, (7), 1767-1778.

[222] Estruch, M.; Minambres, I.; Sanchez-Quesada, J.L.; Soler, M.; Perez, A.; Ordonez-Llanos, J.; Benitez, S., Increased inflammatory effect of electronegative LDL and decreased protection by HDL in type 2 diabetic patients. Atherosclerosis, 2017.

[223] Harper, C.R.; Jacobson, T.A., Managing dyslipidemia in chronic kidney disease. Journal of the American College of Cardiology, 2008, 51, (25), 2375-2384.

[224] Vaziri, N.D., HDL abnormalities in nephrotic syndrome and chronic kidney disease. Nature reviews. Nephrology, 2016, 12, (1), 37-47.

[225] Speer, T.; Rohrer, L.; Blyszczuk, P.; Shroff, R.; Kuschnerus, K.; Krankel, N.; Kania, G.; Zewinger, S.; Akhmedov, A.; Shi, Y.; Martin, T.; Perisa, D.; Winnik, S.; Muller, M.F.; Sester, U.; Wernicke, G.; Jung, A.; Gutteck, U.; Eriksson, U.; Geisel, J.; Deanfield, J.; von Eckardstein, A.; Luscher, T.F.; Fliser, D.; Bahlmann, F.H.; Landmesser, U., Abnormal high-density lipoprotein induces endothelial dysfunction via activation of Toll-like receptor-2. Immunity, 2013, 38, (4), 754-768.

[226] Baragetti, A.; Norata, G.D.; Sarcina, C.; Rastelli, F.; Grigore, L.; Garlaschelli, K.; Uboldi, P.; Baragetti, I.; Pozzi, C.; Catapano, A.L., High density lipoprotein cholesterol levels are an independent predictor of the progression of chronic kidney disease. J Intern Med, 2013, 274, (3), 252-262.

[227] Honda, H.; Hirano, T.; Ueda, M.; Kojima, S.; Mashiba, S.; Hayase, Y.; Michihata, T.; Shibata, T., HighDensity Lipoprotein Subfractions and Their Oxidized Subfraction Particles in Patients with Chronic Kidney Disease. J Atheroscler Thromb, 2016, 23, (1), 81-94.

[228] Honda, H.; Ueda, M.; Kojima, S.; Mashiba, S.; Michihata, T.; Takahashi, K.; Shishido, K.; Akizawa, T., Oxidized high-density lipoprotein as a risk factor for cardiovascular events in prevalent hemodialysis patients. Atherosclerosis, 2012, 220, (2), 493-501. 
[229] Yamamoto, S.; Yancey, P.G.; Ikizler, T.A.; Jerome, W.G.; Kaseda, R.; Cox, B.; Bian, A.; Shintani, A.; Fogo, A.B.; Linton, M.F.; Fazio, S.; Kon, V., Dysfunctional high-density lipoprotein in patients on chronic hemodialysis. Journal of the American College of Cardiology, 2012, 60, (23), 2372-2379.

[230] Kalantar-Zadeh, K.; Kopple, J.D.; Kamranpour, N.; Fogelman, A.M.; Navab, M., HDL-inflammatory index correlates with poor outcome in hemodialysis patients. Kidney Int, 2007, 72, (9), 1149-1156.

[231] Shimizu, T.; Tanigawa, H.; Miura, S.; Kuwano, T.; Takata, K.; Suematsu, Y.; Imaizumi, S.; Yahiro, E.; Zhang, B.; Uehara, Y.; Saku, K., Newly developed apolipoprotein A-I mimetic peptide promotes macrophage reverse cholesterol transport in vivo. Int J Cardiol, 2015, 192, 82-88.

[232] Nguyen, S.D.; Javanainen, M.; Rissanen, S.; Zhao, H.; Huusko, J.; Kivela, A.M.; Yla-Herttuala, S.; Navab, M.; Fogelman, A.M.; Vattulainen, I.; Kovanen, P.T.; Oorni, K., Apolipoprotein A-I mimetic peptide 4F blocks sphingomyelinase-induced LDL aggregation. J Lipid Res, 2015, 56, (6), 1206-1221.

[233] Uehara, Y.; Ando, S.; Yahiro, E.; Oniki, K.; Ayaori, M.; Abe, S.; Kawachi, E.; Zhang, B.; Shioi, S.; Tanigawa, H.; Imaizumi, S.; Miura, S.; Saku, K., FAMP, a novel apoA-I mimetic peptide, suppresses aortic plaque formation through promotion of biological HDL function in ApoE-deficient mice. J Am Heart Assoc, 2013, 2, (3), e000048.

[234] Amar, M.J.; D'Souza, W.; Turner, S.; Demosky, S.; Sviridov, D.; Stonik, J.; Luchoomun, J.; Voogt, J.; Hellerstein, M.; Sviridov, D.; Remaley, A.T., 5A apolipoprotein mimetic peptide promotes cholesterol efflux and reduces atherosclerosis in mice. $J$ Pharmacol Exp Ther, 2010, 334, (2), 634-641.

[235] Iwata, A.; Miura, S.; Zhang, B.; Imaizumi, S.; Uehara, Y.; Shiomi, M.; Saku, K., Antiatherogenic effects of newly developed apolipoprotein A-I mimetic peptide/phospholipid complexes against aortic plaque burden in Watanabe-heritable hyperlipidemic rabbits. Atherosclerosis, 2011, 218, (2), 300-307.

[236] Morgantini, C.; Imaizumi, S.; Grijalva, V.; Navab, M.; Fogelman, A.M.; Reddy, S.T., Apolipoprotein A-I mimetic peptides prevent atherosclerosis development and reduce plaque inflammation in a murine model of diabetes. Diabetes, 2010, 59, (12), 3223-3228.

[237] Vecoli, C.; Cao, J.; Neglia, D.; Inoue, K.; Sodhi, K.; Vanella, L.; Gabrielson, K.K.; Bedja, D.; Paolocci, N.; L'Abbate, A.; Abraham, N.G., Apolipoprotein A-I mimetic peptide L-4F prevents myocardial and coronary dysfunction in diabetic mice. Journal of cellular biochemistry, 2011, 112, (9), 2616-2626.

[238] Khera, A.V.; Demler, O.V.; Adelman, S.J.; Collins, H.L.; Glynn, R.J.; Ridker, P.M.; Rader, D.J.; Mora, S., Cholesterol Efflux Capacity, High-Density Lipoprotein Particle Number, and Incident Cardiovascular Events:

An Analysis From the JUPITER Trial (Justification for the Use of Statins in Prevention: An Intervention Trial Evaluating Rosuvastatin). Circulation, 2017, 135, (25), 2494-2504.

[239] Kim, J.B.; Hama, S.; Hough, G.; Navab, M.; Fogelman, A.M.; Maclellan, W.R.; Horwich, T.B.;

Fonarow, G.C., Heart failure is associated with impaired anti-inflammatory and antioxidant properties of high-density lipoproteins. The American journal of cardiology, 2013, 112, (11), 1770-1777.

[240] Hansel, B.; Giral, P.; Nobecourt, E.; Chantepie, S.; Bruckert, E.; Chapman, M.J.; Kontush, A., Metabolic syndrome is associated with elevated oxidative stress and dysfunctional dense high-density lipoprotein particles displaying impaired antioxidative activity. The Journal of clinical endocrinology and metabolism, 2004, 89, (10), 4963-4971. 


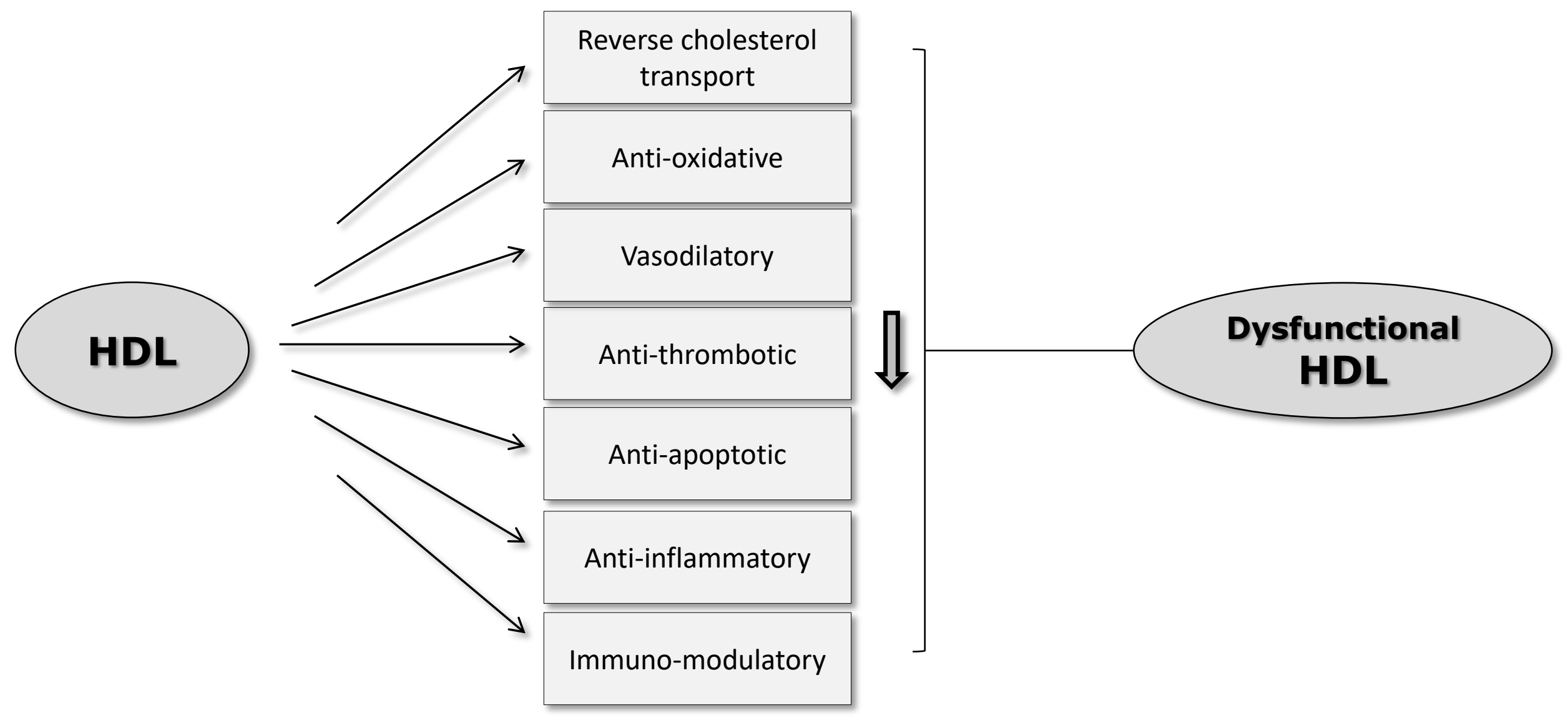

Figure 1 


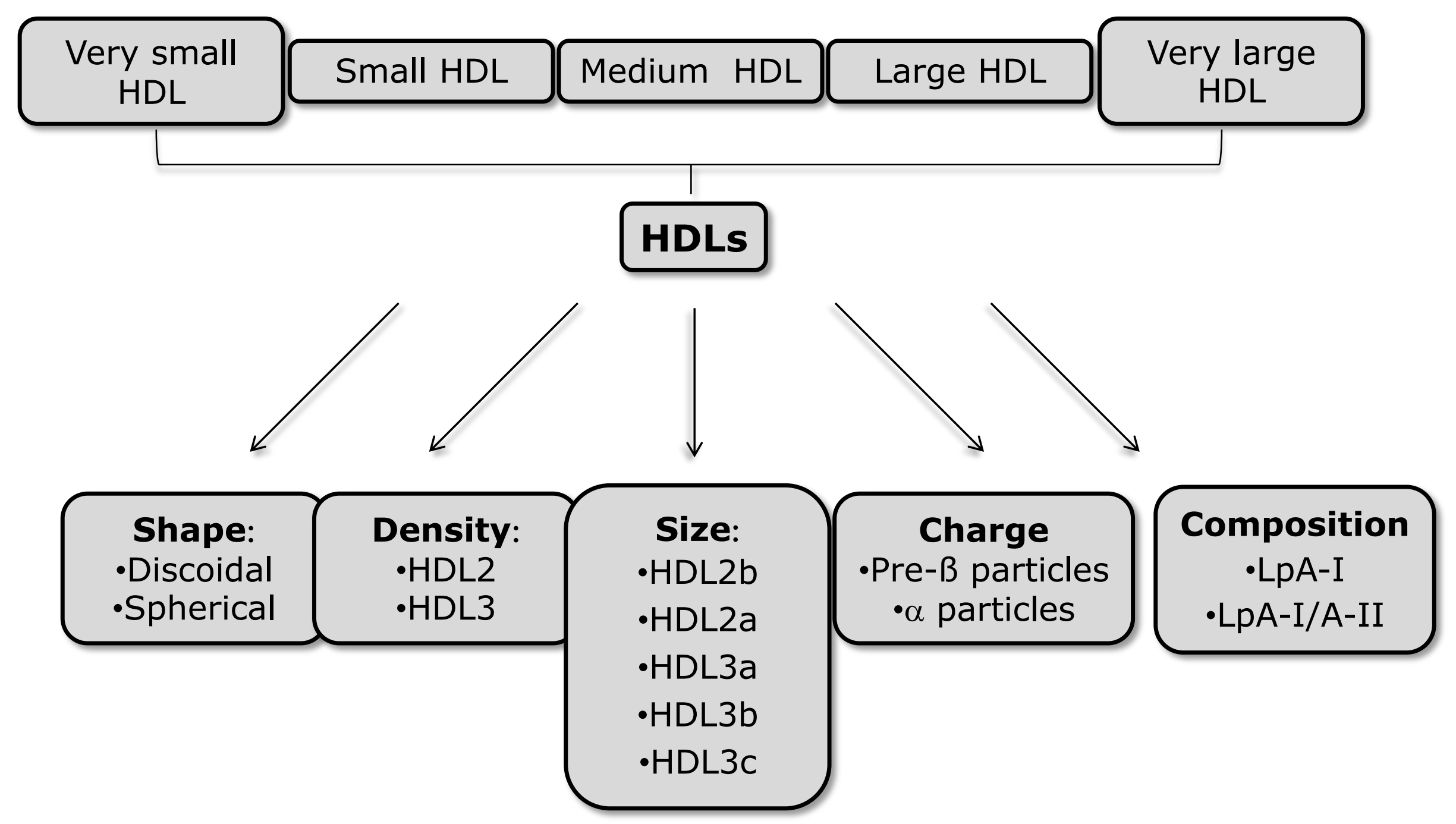

Figure 2 


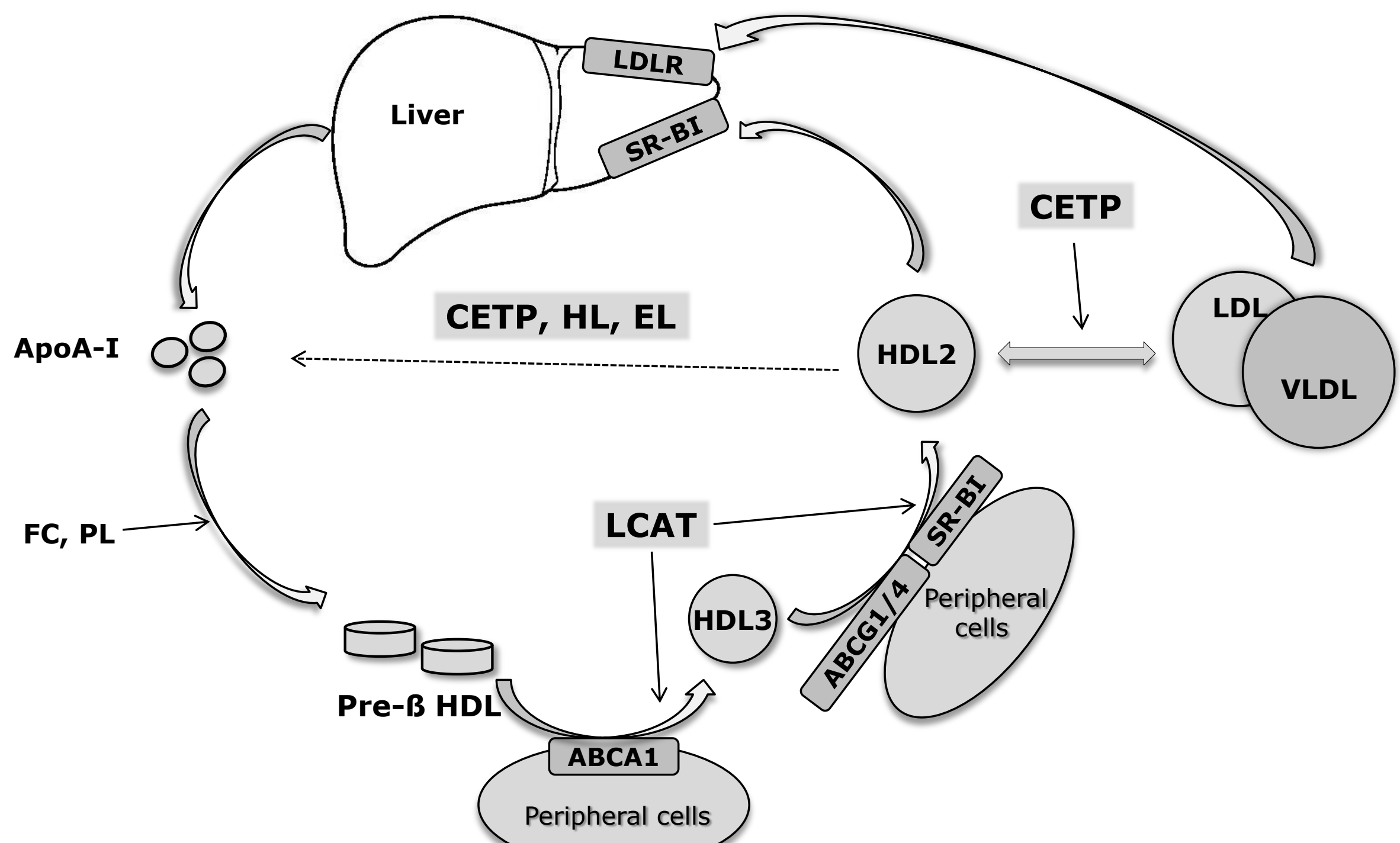

Figure 3 
1. Normal LCAT activity

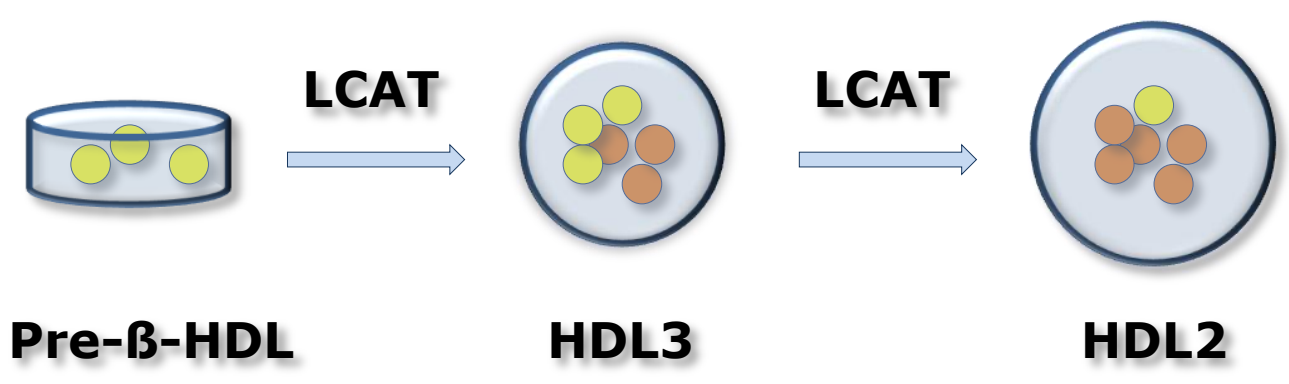

2. LCAT deficiency

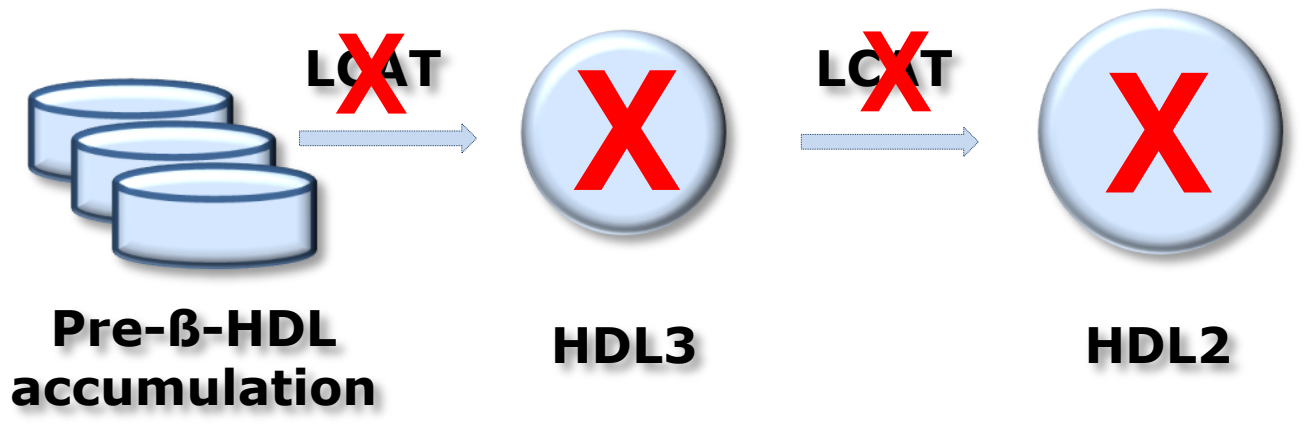

Figure 4 
1. Normal CETP activity

\section{apoB-containing}

lipoproteins

LCAT

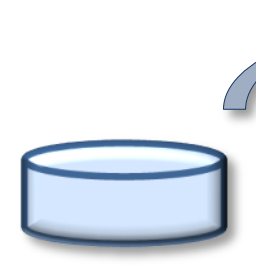

Small HDL

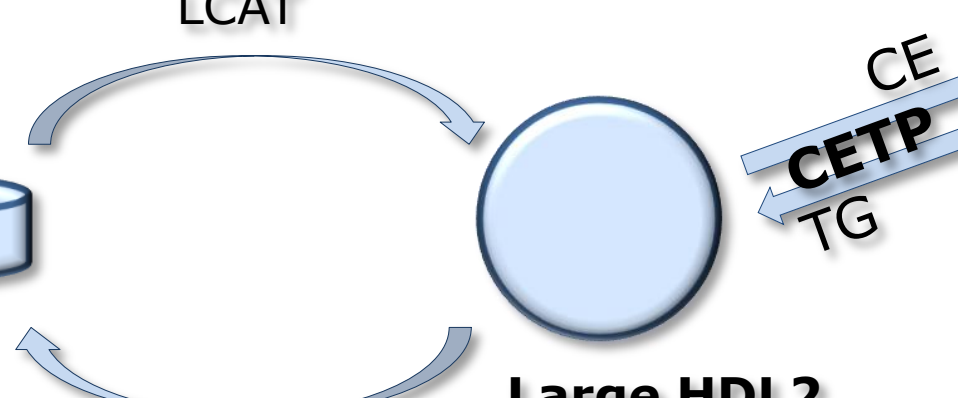

(LDL, VLDL)

\section{CETP, HL}

\section{Large HDL2}

2. CETP deficiency

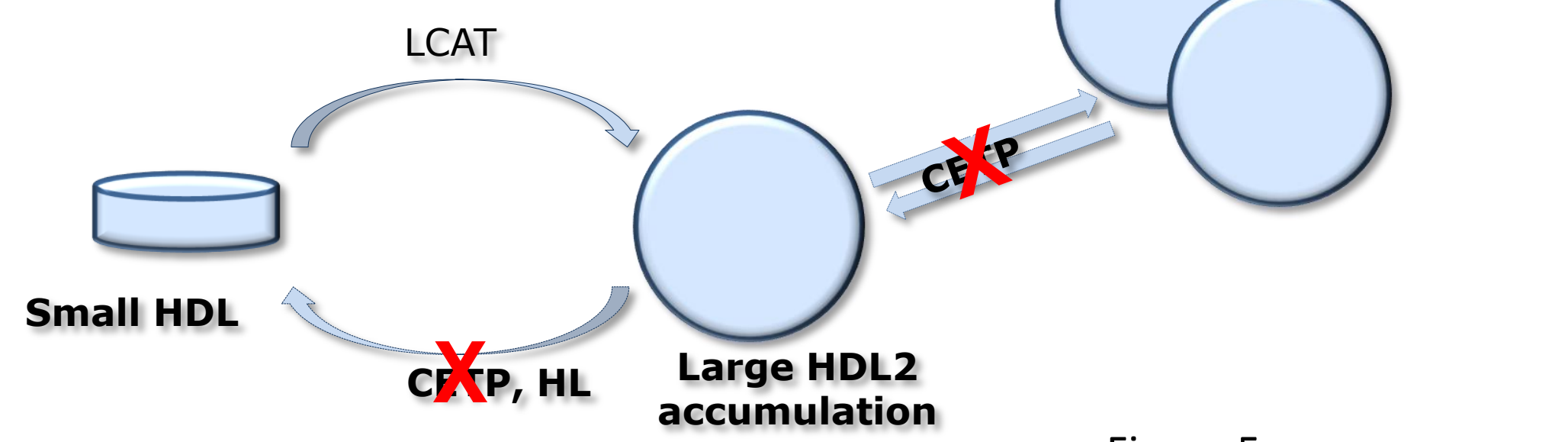

Figure 5 